\title{
The impact of the natural environment on the promotion of active living: An integrative systematic review
}

\author{
Giovanna Calogiuri $^{*}$ and Stiliani Chroni ${ }^{2}$
}

\begin{abstract}
Background: An understanding of how the living environment influences physical activity (PA) is of great importance for health promotion. Researchers have reported increased PA when there is a greater availability of nature within people's living environment. However, little has been said about underlying motivational processes. The aim of this study was to review the existing literature on the relationship between the natural environment (NE) and PA, integrating it into a conceptual model that depicts the motivational process underlying this relationship.

Methods: Through a systematic literature search in line with PRISMA guidelines, peer-reviewed articles were sought using PubMed (search updated to October 2013) and scrutiny of reference lists. In addition, we contacted experts within our network. We reviewed papers in which the research question(s) concerned: 1) Effects of PA in NE on individuals' feelings and beliefs; 2) Relationships between PA and availability of NEs; and 3) Motivational processes underlying visits to NEs in association with PA. Analysis and integration of the 90 selected studies were performed using the theory of planned behaviour (TPB).

Results: People's experiences in using the NE can enhance attitudes toward PA and perceived behavioural control via positive psychological states and stress-relieving effects, which lead to firmer intentions to engage in PA. Individual and environmental barriers, as expressions of social support and actual behavioural control, impact the process via subjective norm and perceived behavioural control. Instrumental beliefs such as a desire to enjoy nature and the expected health benefits also influence the process via attitudes. Different patterns have been identified for neighbourhood-based PA and outdoor recreations that take place in a NE.

Conclusions: The availability of a NE and attractive views of nature within an individual's living environment are important contributors to PA, yet attention should focus on personal characteristics and environmental barriers. Policy and infrastructural interventions should aim to guarantee access and maintenance of the NE, as well as information and programming of social activities. Social campaigns via media and health institutions should highlight how nature can be a source of motivation for maintaining a PA routine, reducing stress and achieving aesthetic and health goals.
\end{abstract}

Keywords: Natural environment, Health promotion, Physical activity, Attitude, Motivation, Exercise

\section{Background}

The benefits of physical activity (PA) in promoting health are well known. Despite this, a large portion of the population still does not meet the minimum recommended levels for PA, to the point that inactivity has been identified as the fourth leading factor in mortality

\footnotetext{
* Correspondence: giovanna.calogiuri@hihm.no

'Department of Dental Care and Public Health, Hedmark University College, Elverum, Norway

Full list of author information is available at the end of the article
}

worldwide [1]. An increase in PA levels among the population is therefore a priority for public health. Policies that aim to encourage active lifestyles must act at a multilevel scale, targeting both the individuals and the living environment to induce behavioural changes in the population [2]. Mode of transport and recreation are two vital domains for an active lifestyle, but their sustainability on an everyday basis is strongly linked to motivational processes as well as environmental characteristics. For example, it has been reported that just the availability 
of PA facilities, such as walking/cycling paths, is not sufficient to encourage people to embrace an active lifestyle [3]. Characteristics of the environment can influence PA behaviours by encouraging or discouraging a person to use the environment for PA purposes, however it is important to take into account how an individual's decision to be active is influenced by a supportive physical environment [4]. In recent years, the attention paid to the role of nature and natural environments (NEs - including green open spaces, neighbourhood gardens and attractive views of nature) that positively impact on PA behaviours has grown. NEs provide opportunities for individuals to engage in PA, so promotion of their importance for health through land-use planning has been advocated [5-7].

Systematic reviews of literature supported the view that the availability of NEs within people's living environment is generally positively related to more PA $[8,9]$. However, contrasting findings have also been reported, because some studies found weak or no associations between the availability of NEs and PA. Furthermore, concerns about the methodologies used have been expressed (e.g. inability to exclude confounding variables and reverse causality) and researchers pointed out the need to identify the motivational processes underlying the relationship between NE and PA for better planning of interventions $[4,9]$. Remarkably, systematic review studies $[10,11]$ supported the finding that, when compared with PA taking place indoors or in urban settings, PA that is in touch with nature provides the individual with more pleasurable experiences, i.e. positive psychological states as well as psychological effects and, to a lesser extent, physiological effects on stress. So far, the 'behavioural' and 'psycho-physiological' outputs associated with the $P A-N E$ relationship have been considered only independently of each other. Although integration of the two perspectives has been proposed, in the attempt to identify possible motivational processes [12-14], solid systematic methodologies and evidence-based approaches are still missing.

\section{Why does nature make us 'feel good'?}

The physiological stress response is a general mobilization of the organism, and involves hormonal and behavioural responses for facing a situation perceived as demanding or threatening to the individual; this can be influenced by physical and social environments [15]. Some psychoevolutionary approaches postulate that human beings are still innately linked to the NE as its natural ecosystem and are not fully adapted to the modernized urban setting, so that an environment devoid of nature may have negative consequences via activation of stress responses (see for example Grinde and Patil [7]). The absence of a NE would be associated with increased stress, and the presence of nature would reduce stress. According to Ulrich's stress recovery theory [16], recovery from stress is facilitated by exposure to scenes that elicit feelings of mild-to-moderate interest, pleasantness and calmness. The theory assigns a restorative advantage to NEs and features of nature over artificial environments [16]. In other theories such as the attention restoration theory of Rachel and Stephen Kaplan [17], cognitive stress occurs primarily as a result of prolonged focus on tasks that are not perceived as interesting (e.g. repetitive work, paying attention to the traffic). Restoration can occur through a form of attention that is spontaneous and 'effortless'. Environments and experiences that provide such resources would produce opportunities for recovery from mental stress. NEs not only provide such opportunities, but also elicit soft fascination processes, which are especially effective at mitigating and preventing stress [17].

The exact mechanism underlying an individual's responses to nature has not yet been conclusively explained. Many theories assign the main effect of exposure to nature to visual 'recognition' [7], an assumption that is also supported by studies using images of nature (e.g. pictures/ videos displayed on a screen) $[16,18]$ and views out of windows $[19,20]$. A recent study identified the colour green as a 'primitive visual feature' of NEs that may contribute to the positive psychophysiological responses to being in touch with nature [21]. Other authors have postulated that some effects of exposure to NEs are induced by substances present in the air - wood essential oils, called phytoncides, produced by trees [22]. Alternatively, it has been suggested that NEs can reduce stress through social support [23,24]. Either way, several studies have shown that exposure to nature can elicit recovery from mental and physiological stress. Furthermore, as stress is tightly linked to psychological states [15], exposure to nature has been shown to provide vitalizing effects and enhanced psychological states, such as improved mood and positive affect $[10,11]$. The processes of stress recovery occurring to people walking in natural environments have recently been displayed by field measurements using a portable electroencephalograph (EEG) [25]. In addition, observational studies have revealed that residential proximity to NEs was associated with (1) reduced levels of perceived stress, possibly due to restorative opportunities eliciting coping mechanisms [26], and (2) biological indicators of stress such as cortisol production [27].

\section{Motivation and active living: How can nature help?}

Ajzen's theory of planned behaviour (TPB [28]) is suggested as one of the psychobehavioural models suitable for explaining motivational processes that underlie the relationship between environments and PA [4]. According to the TPB, behaviour is mainly driven by intention In turn, intention depends on three psychological components: attitude toward the behaviour, subjective norm 
and perceived behavioural control; these are linked to the person's behavioural, normative and control beliefs, respectively. Intention captures a person's motivation and indicates willingness to perform a given behaviour. Attitude refers to a person's favourable or unfavourable evaluation of the behaviour. Subjective norm refers to the social pressure placed on the person to perform or not perform the behaviour. Perceived behavioural control refers to beliefs about the ease or difficulty of performing the behaviour and reflects past experiences, along with obstacles inhibiting the person from performing the behaviour.

According to Ajzen et al. [29]: 'the more favorable the attitude and subjective norm, and the greater the perceived behavioral control, the stronger should be the person's intention to perform the behavior in question.' However, an intention-behaviour gap may occur. In line with the TBP, subjective norm and perceived behavioural control may have a direct effect and weaken the intention-behaviour prediction, even when there is a favourable attitude to engage in a certain behaviour. Actual behavioural control (i.e. the extent to which a person has the skills, resources and other prerequisites needed to perform a given behaviour) also has an important double-sided influence on behaviour by influencing perceived control over the behaviour, as well as the possibility of putting intentions into action [30]. The TPB has shown a strong prediction in determining whether a person will take action in a diverse array of domains. In the context of PA, it has been shown to predict walking where an NE was available [31], as well as participation in outdoor recreation [32].

Experimental studies have shown that positive experiences in PA can positively impact on people's attitudes toward PA and perceived behavioural control, leading to firmer intentions to engage in PA in the future. In turn, the environment in which PA takes place can play an important role when it comes to people's emotions in response to PA. For instance, it was found that walking outdoors, compared with walking indoors on a treadmill, was associated with more enjoyment and positive emotions, as well as a greater intention to engage in PA in the future [33,34]. Thus the positive experiences in NEs may lead to increased engagement in PA via attitudes and perceived behavioural control. However, the impact of the other constructs, such as subjective norm and perceived behavioural control, and other behavioural beliefs (e.g. expected health effects or feelings about nature) must be taken into account.

\section{Objectives}

Using an integrative review of the literature, the current study attempted to find an explanation for how availability of NEs within people's living environment can have a positive effect on PA behaviour. The existing knowledge, approached here through the lens of TPB, provides us with multiple variables on which we may act to motivate people toward healthier active lifestyles.

\section{Methods}

The integrative review method, although criticized as less rigorous than other literature review methods (i.e. systematic reviews and meta-analysis), provided us with the opportunity to incorporate diverse methodologies (i.e. observational and experimental studies) to capture the context, processes and subjective elements of the topic better, and create new knowledge and perspectives [35].

\section{Conceptual criteria}

The term 'natural environment' is used throughout the paper to define open outdoor spaces that allow the individual to be surrounded by the elements of nature (trees, plants, grass, mountains, water, etc.) while engaging in PA. The term also includes outdoor built environments that are rich in vegetation or offer views of nature (green neighbourhoods). In accordance with the definition of PA by the World Health Organization (WHO) [1]: '... includes leisure time physical activity, transportation (e.g. walking or cycling), occupational (i.e. work), household chores, play, games, sports or planned exercise, in the context of daily, family, and community activities.' In an attempt to avoid confounding effects caused by actual inability to engage in PA, the current study was restricted to the 'healthy', non-athletic, adult population. An age cutoff of 16 years was chosen because it was found to be a cut-off age used in several studies. The literature search aimed to include peer-reviewed articles, in which the research question concerned:

1. Effects of PA in an environment of nature on individuals' feelings and beliefs

2. Relationships between PA levels and availability of NEs within the living environment

3. Motivational processes and reasons underlying visits to NEs in association with PA.

\section{Literature search}

Attention paid to search methodologies can enhance an integrative review's scientific validity [35]. As such, the literature search was based on a systematic review methodology, in line with the PRISMA statement [36]. Sources included databases and scrutiny of reference lists. In addition, we contacted behavioural and environmental psychology experts within our network (searches were guided by experts in the field of behavioural and environmental psychology who were known to the authors). At first, a literature search was performed on PubMed. Keywords used for the search were: green space, natural 
environment*, outdoor*, park or parks, in combination with exercise or physical activity. Keywords were chosen on the basis of previous studies and through a preliminary investigation of the relevant literature. The combinations of keywords resulted in a total of 1273 titles (updated to October 2013), applying the filter 'field search for abstract/title' and considering publications only in English with an abstract. Twenty-nine additional publications were identified through our network. Throughout the scrutiny process, 73 studies were included (Figure 1). Reasons for excluding papers were:

1. The presence and independent effect of NEs was not clearly stated

2. There was no measure of PA

3. PA was occupational or had athletic/competitive purposes

4. Although PA and NEs were measured or clearly reported, the study did not fall within one of the three above-mentioned inclusion criteria.

Studies that were considered to be duplicates or redundant were also excluded. The literature search was then extended to the reference lists of the selected publications, identifying 17 additional publications. A review protocol was not registered.

\section{Extraction and integration of the studies}

All records were screened for eligibility and then reviewed by the first author. Basic information was extracted from the included papers and reported on a standardized spreadsheet. Tables were created and used for analysis, which was performed by the first author. The analysis tables and notes produced were then reviewed by the second author and disagreements discussed until consensus was reached. As the reviewed studies used a large variety of research designs, we were unable to identify a standardized instrument that could have been appropriately applied to all individual studies for quality assessment purposes. Alternatively, we reported sample sizes and study design for all the papers included (see, for example, Des Jarlais et al. [37] and Lu et al. [38]).

\section{Integration and theoretical framework}

Major themes were created on the basis of recurrent issues emerging from the papers included [39], but special

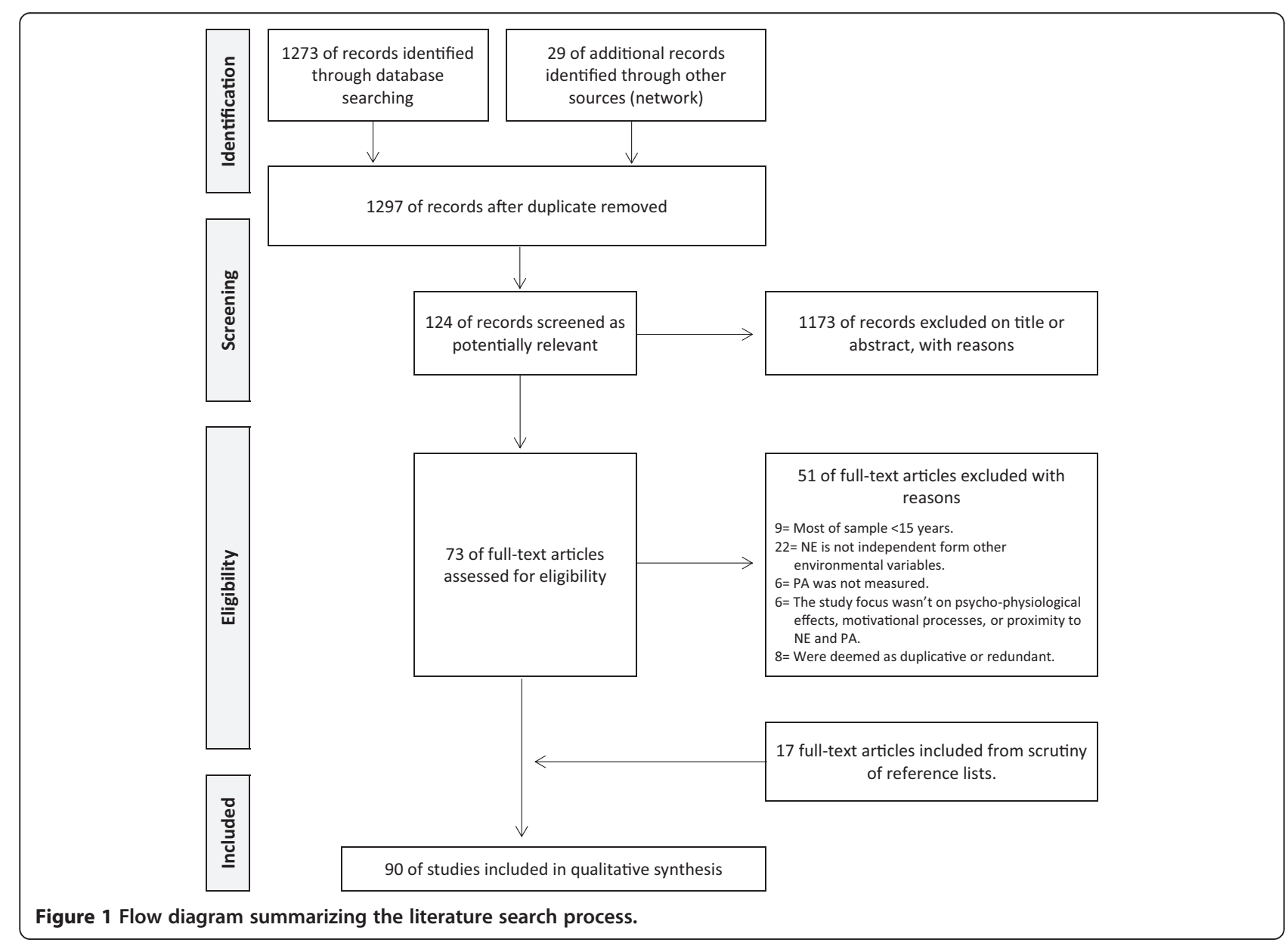


attention was paid to organizing the themes in line with the TPB. Other theories used to inform our analysis and interpretations of the reviewed studies were Ulrich's stress reduction theory [16] and the Kaplans' attention restoration theory (ART) [17]. Last, the constructs identified in the reviewed studies that conceptually appear to fit the TPB model were portrayed graphically (Figure 2).

\section{Results}

Ninety papers were included in the current integrative review (Tables 1 and 2). Of these, 7 were reviews of literature (of which 4 used systematic methodologies Table 2), 62 used observational design (4 were quasiexperimental and 4 prospective cohort studies), 1 was a report using meta-analysis for many studies and 20 reported experimental studies. All studies but one used quantitative methods. Overall, the studies included a total of $1,331,771$ participants. Although many of them used generic samples of 'adults' (i.e. aged $\geq 16$ or 18), some studies focused on age-specific groups, sampling a total of 15,060 adolescents,1,176 young adults, 15,266 middle aged, and 5,173 older adults.
For the purposes of the current study dependent variables were classified as the four main constructs of the TPB: behavioural beliefs ('positive psychological states', 'stress relief', 'instrumental beliefs'), normative and control beliefs (including social support, and individual and environmental barriers), intention (including explicit environmental preference and motives for visiting NEs) and PA behaviour (Table 3). As behavioural beliefs, we classified positive psychological states that were mainly measured as 'mood' or 'positive affect' [21,40-55]. Other outcomes measured were 'enjoyment' [56], 'general happiness' [42] and 'self-esteem' $[45,46,48]$. One observational study also used indicators of mental health [57]. Stress relief was measured by both self-reported and biological indicators of stress. The former included mainly perceived stress $[23,27,58]$ or the environment's perceived potential for restoration [42-44,59,60], whereas the latter included mainly measurements of stress hormones $[22,27,40,54,55]$ and cardiovascular parameters $[42,43,45,47,61]$. Other biological measurements of stress included performance in attention tasks [42-44,52], brain waves on a mobile EEG [25] and salivary amylase [62]. Last, instrumental beliefs, such as perceived benefits

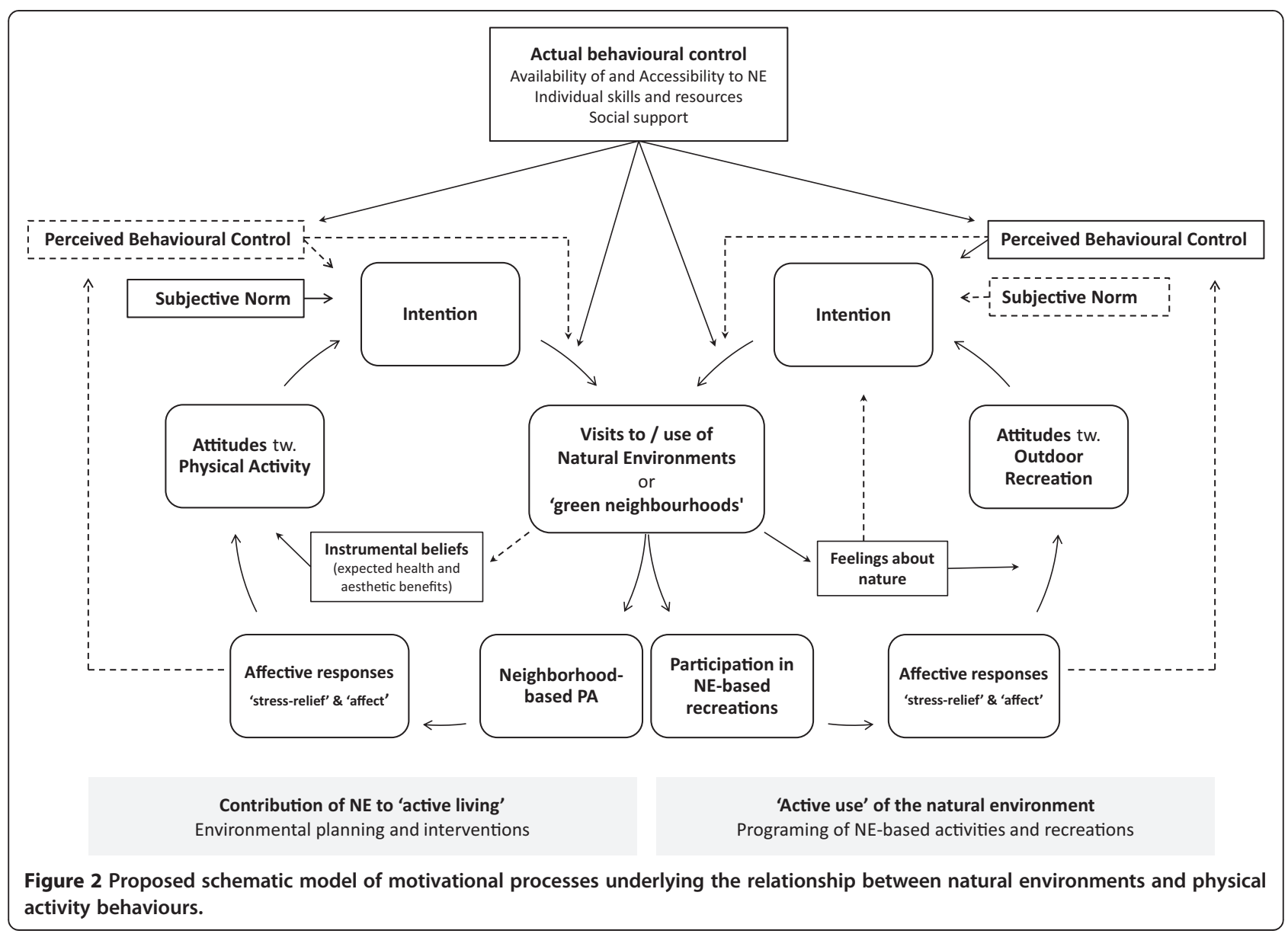


Table 1 Summary of papers included that report original research

\begin{tabular}{lll}
\hline AUTHORS & SAMPLE SIZE & STUDY DESIGN \\
\hline Akers et al. & 14 young male adults & Experimental trial, with pre-test \\
(2012) [21] & & measurements and within-subjects, \\
& non-counterbalanced design. No \\
& control group.
\end{tabular}

Anderson et al. 446 adults, 'proximate/resident' Cross-sectional study (random (2008) [91] and 'distant/non-resident' sampling) and onsite survey visitors (purposeful sampling). fishing, camping, and motor control group.

893 adults living nearby parks Cross-sectional study among residents within .5 miles from 60 parks

\section{Bai et al.}

12 experienced runners
Meta-analysis of 10 studies with matching measurements. Individua studies used pre-measurements with non-randomized allocation (self-selecting)

Experimental trial using mixed design with counterbalanced

Cross-sectional study using stratified random sampling design.

Availability of NEs with high recreational and restorative value in suburban and rural areas.

Genial PA. Self-reported

Experimental trial with pre-test measurements and counterbalanced Exposure to a NE (natural reserve). Running. Standardized activity Standardized setting

cross-over design (two treatments).

Random allocation (method

not described)

Experience of PA in different NES. Standardized setting

\section{Various green exercise}

Experience of PA in an arboretum/ park. cross-over. Random allocation.

\section{EXPERIENCE OF THE NATURAL \\ ENVIRONMENT (NE)}

Exposure to colour-manipulated

videography of NEs. Standardized setting

Visitation of naturalistic parks (lake area). Standardized setting

Experience of PA in an urban green-area (park). Standardized setting Objective measure

SUMMARY OF FINDINGS

Availability and perceived quality of urban parks. Self-reported

Walking. Standardized activity
Outdoor recreation such as boating. Self-reported

Overall moderate to vigorous

Self-reported

Cycling. Standardized activity

\section{The colour green was associated with} greater improvements of post-exercise total mood and lower ratings of perceived exertion while exercising.

Important benefit factors to NEs visitors were 'enjoy nature', 'mental and physical health', and 'social interaction'. For people living nearby a NE, 'solitude' and 'learning' were also important benefit factors.

Measurements of brain-waves activity by a mobile EEG showed stress recovery mechanisms in line with Attention-Restoration Theory (Kaplan \& Kaplan, 1989).

There was a strong agreement among residents that having neighbourhood parks is a benefit. Perceived quality of parks is a bentit. Perceived quality of overall and park-based PA.

A dose-response effect of green-exercise on mood and self-esteem. All types of NEs elicited greater post-exercise improvements, with different patterns identified for subjects' age, time of exposure and PA intensity.

When compare to walking in an urban setting, walking in a NE after a mentalfatiguing-task was associated with improved performance in an attention task, which was not driven by changes in mood.

Residential proximity to NEs was associated with neighbour satisfaction time spent on PA and normal or low BMI. A positive effect on vitality in women was also found.

PA in the natural environment was associated with greater potential for restoration, while statistically significance was not achieved for affective responses and attention performance. The subjects and attention performance. The subjects
reported to prefer running in the natural environment. 
Table 1 Summary of papers included that report original research (Continued)

\begin{tabular}{lll}
\hline $\begin{array}{l}\text { Boone-Heinonen } \\
\text { et al. (2010) [83] }\end{array}$ & 10,773 adolescents & $\begin{array}{l}\text { Cross-sectional study (sampling } \\
\text { technique reported elsewhere). }\end{array}$ \\
$\begin{array}{ll}\text { Butryn \& Furts, } 30 \text { female experienced runners } & \begin{array}{l}\text { Experimental trial using mixed } \\
\text { design with counterbalanced } \\
\text { cross-over. Random allocation } \\
\text { not specified. }\end{array}\end{array}$
\end{tabular}

Cerin et al.

(2008) [56]

Cerin et al.

(2013) [75]

Cohen et al

(2007) [76]

Coogan et al.

(2009) [93]

Coombes et al.

(2010) [94]

Coutts et al

(2013) [95]

Cummins \& Fagg

(2012) [96]

time-periods. Sampling technique
2,650 adults

1,318 adults

20,354 Afro-American women Prospective cohort study. Recruitment Availability of urban parks. based on subscription to a magazine. Objective measure

Cross-sectional study using single stage sampling based on elector wards (equal size populations selected).

Cross-sectional study. Sampling technique not reported.

Cross-sectional study over two not reported. spaces. Self-reported urban area. Self-reported

Availability of urban parks. Objective measure (onsite observation) Objective measure
Amount of green spaces and availability of parks in urban areas. Objective measure

Experience of PA in an urban park

Wheel-based activities, active sports and Self-reported

Running. Standardized activity responses after running in the two environments, despite most of runners reported to prefer the NE. Safety issues may influence the experience of PA in the $\mathrm{NE}$ and consequent affective responses.

Leisure time physical activity. Self-reported NEs in urban areas, including beaches/coasts trails and open

Presence of nature elements within the neighbourhood in

Park-based PA. Assessed through direct observation

Leisure time walking and other PA Self-reported

Utilitarian- and, exercisewalking. Self-reported

Availability of urban green-spaces.

Availability of green-spaces within counties. Objective measure

Availability of nature elements within the neighbourhood in urban and rural. Objective measure

Availability of NEs within the neighbourhood was associated with PA. Other attributes of the environment such as noise/air pollution, availability of spaces for walking and safety, were also predictors of PA.

The NE was an important source for PA opportunity for the users. Furthermore residential proximity to NEs was associated with frequency visitation the NE and PA. Men used the NE for PA purposes more often than women

A weak association was found between distance to NEs and PA. Other factors associated with PA related to housing density, bus availability and access to transit.

General PA. Self-reported

Residential proximity to NEs, especially those classified as 'formal green spaces', was associated with higher PA and lower probability to be overweight or obese.

Moderate to vigorous PA. Self-reported

Overall amount of NE within the county was positively associated with PA.

General PA. Self-reported

Mixed results were found in the relationship between obesity/ overweight and residential proximity to NEs, with PA not mediating the relationship. Living in urban or rural areas was instead a relevant factor. 
Table 1 Summary of papers included that report original research (Continued)

Day (2008) [90]

45 older adults

Qualitative, case study. Purpose

Availability of nature elements (e.g. presence of gardens, sea view, trees, etc.) within the living environment Self-reported and direct observation

Walking and general PA habits. Self-reported

Duvall \& Young 62 experienced walkers (2013) [89]
Observational study using a purposeful sample. Subjects

Use of nearby nature. recruitment through announcement.

Cross-sectional study (three-stage random sampling technique) and definition of a conceptual model. parks within the neighbourhood. Moderate to vigorous PA. Self-reported

Objective measure

Cross-sectional study using multi-cluster random sampling design.

Cross-sectional study. Recruitmen through approach by general practitioner.

Experimental trial with counterbalanced cross-over desig and control group (indoors with no PA). Random allocation not specified.

Multi-level cross-sectional study using a two-stage randomized sampling design.
Availability of parks and open

spaces within the neighbourhood

(urban and rural areas).

Self-reported

Availability of urban green-spaces Different types of PA, for (nature reserve, river walk, or public park). Objective measure

Exposure to actual and 'virtual' NEs with different characteristics. purposes. Self-reported

Walking. Standardized activity

\section{Walking. Self-reported}

Availability of urban parks within the neighbourhood. Objective measure
WalkingSelf-reported
Availability of vegetation and
NE was an important motivational factor to engage in PA for pleasure. Cleanliness, aesthetic, and restorative potential were environmental characteristics encouraging older people to go outdoors, for walking and socializing. Among the physical barriers, quality of the pavement was the most important

To set health goals and using good walking paths, especially using nearby nature, were the most useful strategies to sustain walking routines among experienced walkers. Social support was the least useful strategy, although it was associated with other types of PA.

PA was directly associated with availability of NEs and indirectly associated with reduced stress via improved social support. NE was positively associated with reduced stress, although different components of neighbourhood green had different influences on stress mitigation.

The availability of NEs was associated with PA in men, while walking behaviour in women was more influenced by perceived safety.

There was no association between availability of NEs and PA. Traffic intensity had a negative impact on cycling.

Compared to a NE with low prospect/ accessibility and high refuge characteristics, a NE with high prospect/ accessibility and low refuge were associated with greater improvement of mood. On the other hand low prospect/ high refuge certain types of NEs may be responsible for more stress due to increased fear.

Associations between availability of NEs and PA were found. Other factors influencing PA behaviour were safety from traffic, pavement slope and connectivity. 
Table 1 Summary of papers included that report original research (Continued)

\begin{tabular}{|c|c|c|c|c|c|}
\hline $\begin{array}{l}\text { Gomez et al. } \\
\text { (2010) [84] }\end{array}$ & 1,315 adults & $\begin{array}{l}\text { Multi-level cross-sectional study } \\
\text { using stratified and cluster sampling } \\
\text { design. }\end{array}$ & $\begin{array}{l}\text { Availability of urban parks within } \\
\text { the neighbourhood. Objective } \\
\text { measure }\end{array}$ & Leisure time PA. Self-reported & $\begin{array}{l}\text { The availability of NEs predicted irregular } \\
\text { and regular PA. Other environmental } \\
\text { factors predicting PA were better } \\
\text { connectivity and smaller pavement } \\
\text { slope. }\end{array}$ \\
\hline $\begin{array}{l}\text { Harte \& Eifert } \\
\text { (1995) [40] }\end{array}$ & 10 male adults & $\begin{array}{l}\text { Experimental trial with } \\
\text { counterbalanced cross-over design } \\
\text { (three exercise-treatments and a } \\
\text { control). Randomized allocation } \\
\text { (method not described) }\end{array}$ & $\begin{array}{l}\text { Garden of a University Campus } \\
\text { and indoor reproduction of } \\
\text { outdoors sounds. Standardized } \\
\text { setting }\end{array}$ & Running. Standardized activity & $\begin{array}{l}\text { PA in an outdoor NE was associated } \\
\text { with an external focus of attention, } \\
\text { greater likability, improved mood and } \\
\text { lower production of stress hormones } \\
\text { as compared with PA indoors. }\end{array}$ \\
\hline $\begin{array}{l}\text { Hartig et al. } \\
\text { (1991) [42] }\end{array}$ & 102 adults & $\begin{array}{l}\text { Two studies: Quasi-experimental } \\
\text { with pre-test measurements on } \\
\text { three groups (one control). } \\
\text { Experimental trial with pre-test } \\
\text { measurements and between-subjects } \\
\text { design (two treatments and a } \\
\text { control). Randomized allocation } \\
\text { (method not described) }\end{array}$ & $\begin{array}{l}\text { Experiences in wilderness } \\
\text { environment and a natural } \\
\text { reserve. Spontaneously chosen } \\
\text { environment and standardized } \\
\text { setting }\end{array}$ & $\begin{array}{l}\text { Vacation experiences and } \\
\text { walking. Self-reported and } \\
\text { standardized activity }\end{array}$ & $\begin{array}{l}\text { Experiences in NEs were associated } \\
\text { with greater restorative effects, overall } \\
\text { happiness and improved cognitive } \\
\text { performances as compared to the other } \\
\text { experiences. Some effects on positive } \\
\text { affect were also found. No effects were } \\
\text { found on physiological indicators of } \\
\text { stress (blood pressure and heart rate) }\end{array}$ \\
\hline $\begin{array}{l}\text { Hartig et al. } \\
\text { (2003) [43] }\end{array}$ & 112 students & $\begin{array}{l}\text { Experimental trial with between- } \\
\text { subjects design (two treatments). } \\
\text { Random allocation stratified by } \\
\text { gender (method not described). }\end{array}$ & $\begin{array}{l}\text { Natural reserve adjacent to a } \\
\text { forest. Standardized setting }\end{array}$ & $\begin{array}{l}\text { Passive contemplation and } \\
\text { walking. Standardized activity }\end{array}$ & $\begin{array}{l}\text { As compared to PA in a urban setting, } \\
\text { PA in a NE elicited a reduction of the } \\
\text { blood pressure, an improvement of } \\
\text { attention and cognitive performance, } \\
\text { and greater positive psychological } \\
\text { responses (positive affect and } \\
\text { reduced anger). }\end{array}$ \\
\hline $\begin{array}{l}\text { Hillsdon et al. } \\
\text { (2006) [98] }\end{array}$ & 4,950 middle-aged adults & $\begin{array}{l}\text { Cross-sectional study. Recruitment } \\
\text { through approach by general } \\
\text { practitioner. }\end{array}$ & $\begin{array}{l}\text { Availability of urban green-spaces. } \\
\text { Objective measure }\end{array}$ & General PA. Self-reported & $\begin{array}{l}\text { No statistical evidence of a relationship } \\
\text { between availability of NEs and PA } \\
\text { was found. }\end{array}$ \\
\hline $\begin{array}{l}\text { Hoehner et al. } \\
\text { (2010) [64] }\end{array}$ & $\begin{array}{l}7 \text { parks implementing } \\
\text { interventions targeting } \\
\text { different audiences (general } \\
\text { park visitors, tourists, employees } \\
\text { from nearby businesses and } \\
\text { youths) }\end{array}$ & $\begin{array}{l}\text { Synthesis of findings from seven } \\
\text { quasi-experimental cases, each of } \\
\text { which used pre- measurements. }\end{array}$ & $\begin{array}{l}\text { National and urban parks. } \\
\text { Standardized settings }\end{array}$ & $\begin{array}{l}\text { Park-based activities, such as } \\
\text { walking, hiking, biking on } \\
\text { trails and kayaking. Self- } \\
\text { reported, onsite observation } \\
\text { and existing interventions }\end{array}$ & $\begin{array}{l}\text { The interventions showed some effects } \\
\text { on awareness of PA benefits on health } \\
\text { and in encouraging 'active' use of NEs. } \\
\text { Parks offer important sources of PA, } \\
\text { and relatively simple and low-cost } \\
\text { interventions can efficiently promote PA. }\end{array}$ \\
\hline $\begin{array}{l}\text { Hug et al. } \\
\text { (2009) [59] }\end{array}$ & 319 members of fitness centres & $\begin{array}{l}\text { Onsite survey (subjects approached } \\
\text { for interview) }\end{array}$ & $\begin{array}{l}\text { Outdoor NE with features for PA } \\
\text { and exercise. Standardized setting }\end{array}$ & Gym-based PA. Self-reported & $\begin{array}{l}\text { The NE was reported to provide greater } \\
\text { potential for restoration than the } \\
\text { indoor-exercise setting. Different } \\
\text { restorative qualities predicted exercise } \\
\text { frequencies in the different environments, } \\
\text { with compatibility predicting frequency } \\
\text { of PA in the NE. The use the NE was } \\
\text { influenced by season and weather. }\end{array}$ \\
\hline $\begin{array}{l}\text { Kaczynski \& Mowen } \\
\text { (2011) [99] }\end{array}$ & 585 adults & $\begin{array}{l}\text { Cross-sectional study using random } \\
\text { sampling design (respondents } \\
\text { selected from a property list). }\end{array}$ & $\begin{array}{l}\text { Availability of urban parks. } \\
\text { Objective measure (method } \\
\text { not described) }\end{array}$ & Park based PA. Self-reported & $\begin{array}{l}\text { Access to NEs was positively associated } \\
\text { with PA. The association appear to not } \\
\text { be determined by a self-selection } \\
\text { phenomenon. E.g. people giving greater } \\
\text { importance to NEs did not necessarily } \\
\text { reside in areas with greater access to it. }\end{array}$ \\
\hline
\end{tabular}

thod not described)

Cross-sectional study. Recruitment through approach by genera practitioner

Synthesis of findings from seven quasi-experimental cases, each of interventions targeting different audiences (general from nearby businesses and youths)

Hug et a.

319 members of fitness centres for interview) sampling design (respondents Objective measure (method not described) 
Table 1 Summary of papers included that report original research (Continued)

\section{Kaczynski et al. $\quad 380$ adults}

(2008) [85]

(2008) [85]

Kaczynski et al. $\quad 384$ adults

(2009) [79]

Karusisi et al.

(2012) [63]

Kerr et al.

(2006) [41]

King et al.

(2012) [100]

Kouthouris \&

Spontis (2005) [32]
Cross-sectional study. Sampling

through systematic selection of

household in four neighbourhoods.

Availability and quality of urban parks. Objective measure

Par

Park-based PA. Self-reported

\section{Num}

Number of features and, to a lesser weresidential proximity were significantly associated with use of a NE for PA purposes. Paved trials,
unpaved trials and wooded areas were the stronger predictors of PA. Natural parks interconnected by trails may be effective for PA promotion.

Cross-sectionat study. Sampling through systematic selection of household in four neighbourhoods.

Availability of urban parks within the neighbourhood. Objective

Moderate to vigorous PA (general, neighbourhoodand park-based). Self-reported

Availability of NEs predicted the residents meeting minimum recommended PA levels, both general and park-based. Women, younger and older individuals were more likely to meet minimum recommended PA available around home.

Cross-sectional study. Recruitment Availability of urban green and Jogging. Self-reported during health check-up (without a priori sampling). open spaces within the neighbourhood. Objective measure

Availability of NEs predicted PA behaviour (frequency and location), with neighbourhood experiences and attitudes towards health being only a modest mediator. Other factors modest mediator. Other factors predicting PA behaviour were
socio-economic status, perceived socio-economic status, perceived neighbourhood's social cohesion, having friends.

Two experimental trials with counterbalanced cross-over design Standardized setting (two treatments). Random allocation not specified.

Multi-level cross-sectional study. Cluster and stratified random sampling design was used.

Observational and intervention (invitation to participate in an outdoor program). Convenience sample with recruitment through announcements.
Garden of a University Campus.

Availability of urban parks both referring to smaller and larger parks (type of park not assessed). Objective measure

PA in a NE vs. PA indoors showed patterns for competitive or recreational runners. The former reported greater rating of tension and effort, while the latter yield greater 'pride'.

Walking. Self-reported

Total NE area and proximity to NEs were respectively not associated and negatively associated with PA.

Different setting for outdoors

Outdoor recreation program, including lake canoe/kayak orienteering, and archery. Existing intervention different effects on mood, with different recreations. Standardized setting
Theory of planned behaviour well predicted PA behaviour in the NE. PA was predicted by intention, which was in turn predicted by attitudes and perceived behavioural control. Subjective norm did not weight in the applied model, while an effect was observed for the added variable 'role identity. 
Lackey \& Kaczynski 574 adults

(2009) [69]
Cross-sectional study using random sampling design (respondents selected from a property list.

Cross-sectional study using spatial randomized sampling design.

(2008) [101]

608 adults

Li (2010) [22]

49 adults overall

Li et al. (2011) [61] 16 male adults

Librett et al

(2006) [102]

Maas et al.

(2008) [103]

4,899 representing the overall population sampling.

Monographic review of a series of Experiences of Shinrinyoku studies. The individual studies were (forest bathing trips).

experimental trials with non-

counterbalanced cross-over design

(two treatments).

Experimental trial with pre-test measurements and non-

counterbalanced cross-over design

(two treatments).

Cross sectional using a stratified random sampling design.

Use of trails. Self-reported

orest environments. Standardized setting views within the neighbourhood urban area). Objective measure

Walking, cycling, moderate and vigorous PA. Self-reported

rk- and neighbourhoodbased PA. Self-reported

Walking in forest environment.$$
\text { activity }
$$
in mood were also in urban environment, and reduced blood pressure, stress hormones and improve the profile of metabolic parameters.

General moderate to vigorous PA and trails visitation. Standardized activity

Trail-users were more likely to achieve minimum recommended levels of PA. Presence of NEs was reported to be important for choosing a place where to live.

Walking, cycling, sport activities and gardeningSelf-reported

In general, there was no significant association between availability of NES and overall PA, e.g. meeting minimum recommendations. A negative relationship was found for cycling while only gardening was positively while only gardening was positively associated with availability of NES. Age-related differences were obser subjects design and pre-test

Shinrin-yoku (forest bathing trips) setting, PA in the NE was associated with improved mood and profile of with improved mood and profile
physiological indicators of stress physiological indicators of stress
(cortisol and immune parameters). 
Table 1 Summary of papers included that report original research (Continued)

\begin{tabular}{|c|c|c|c|c|c|}
\hline $\begin{array}{l}\text { Mason, Kearns \& } \\
\text { Bond (2011) [68] }\end{array}$ & 5,657 adults & $\begin{array}{l}\text { Cross sectional study using random } \\
\text { stratified sampling design. }\end{array}$ & $\begin{array}{l}\text { Availability of urban parks and } \\
\text { open spaces within the } \\
\text { neighbourhood. Self-reported }\end{array}$ & Walking. Self-reported & $\begin{array}{l}\text { Use and quality of NEs, along with } \\
\text { general shops, were associated with } \\
\text { more PA. Physical (perceived safety) } \\
\text { and social aspects were the strongest } \\
\text { predictors of PA. }\end{array}$ \\
\hline $\begin{array}{l}\text { Mayer et al., } \\
2009 \text { [53] }\end{array}$ & 232 young adults overall & $\begin{array}{l}\text { Multiple experimental study using } \\
\text { between-groups design with } \\
\text { pre-test measurements. Random } \\
\text { allocation not specified. }\end{array}$ & $\begin{array}{l}\text { Experience of PA in natural } \\
\text { settings and exposure to } \\
\text { 'virtual reality. }\end{array}$ & Walking. Standardized activity & $\begin{array}{l}\text { As compared with urban settings, } \\
\text { walking in a NE was associated with } \\
\text { improved connectedness to nature } \\
\text { and positive emotions, with } \\
\text { connectedness to nature mediating the } \\
\text { effects on positive emotions. Experiences } \\
\text { of real nature led to greater effects than } \\
\text { experiences of virtual nature did. }\end{array}$ \\
\hline $\begin{array}{l}\text { McGinn et al. } \\
\text { (2007) [104] }\end{array}$ & 1,659 adults & $\begin{array}{l}\text { Cross-sectional study. Random digit } \\
\text { dialled phone survey. }\end{array}$ & $\begin{array}{l}\text { Perception of urban } \\
\text { neighbourhood physical } \\
\text { characteristics including natural } \\
\text { elements as barriers to PA. } \\
\text { Objective and self-reported } \\
\text { measures }\end{array}$ & $\begin{array}{l}\text { Leisure and transportation PA. } \\
\text { Self-reported }\end{array}$ & $\begin{array}{l}\text { There was little agreement between } \\
\text { objective and perceived measurements } \\
\text { of the environment. Perception of } \\
\text { environmental barriers to PA } \\
\text { (e.g. presence/lack of trees) was } \\
\text { associated with different outcomes } \\
\text { of PA. }\end{array}$ \\
\hline $\begin{array}{l}\text { Michael et al. } \\
\text { (2010) [80] }\end{array}$ & 513 older men & $\begin{array}{l}\text { Prospective cohort study. } \\
\text { Recruitment through clinical sites } \\
\text { and stratified sampling. }\end{array}$ & $\begin{array}{l}\text { Availability of urban parks and } \\
\text { trials within the neighbourhood. } \\
\text { Objective measure }\end{array}$ & Walking. Self-reported & $\begin{array}{l}\text { Older men living closer to a NE had } \\
\text { increased probability to maintain or } \\
\text { increase amounts of PA as compare } \\
\text { to men living farther from NEs. Though, } \\
\text { socio gradient was observed. }\end{array}$ \\
\hline $\begin{array}{l}\text { Michimi \& Wimberly } \\
\text { (2012) [105] }\end{array}$ & 931,116 adults overall & $\begin{array}{l}\text { Two cross-sectional studies. Random } \\
\text { digit dialled phone survey. }\end{array}$ & $\begin{array}{l}\text { Proximity to outdoor recreational } \\
\text { opportunities and availability of } \\
\text { natural amenities in non- } \\
\text { metropolitan areas. Objective } \\
\text { measure }\end{array}$ & General PA. Self-reported & $\begin{array}{l}\text { There was a positive association } \\
\text { between availability of NE and PA, } \\
\text { which was also associated with lower } \\
\text { risk for obesity. }\end{array}$ \\
\hline Mitchell (2012) [57] & 3,750 adults & $\begin{array}{l}\text { Cross-sectional study. Sampling } \\
\text { design not described. }\end{array}$ & $\begin{array}{l}\text { Experiences of PA in different NES } \\
\text { (forest, woodland, open space, or } \\
\text { park). Self-reported }\end{array}$ & General PA. Self-reported & $\begin{array}{l}\text { PA in quality NEs as compared to PA } \\
\text { in other environments was associated } \\
\text { with a lower risk for poor mental health. }\end{array}$ \\
\hline $\begin{array}{l}\text { Morita et al., } \\
2007 \text { [51] }\end{array}$ & 498 adults & $\begin{array}{l}\text { Experimental/Quasi-experimental } \\
\text { trial using a mixed design with } \\
\text { repeated measurements. Probable } \\
\text { self-selection. Random allocation } \\
\text { not specified. }\end{array}$ & Shinrin-yoku (forest bathing trips) & $\begin{array}{l}\text { Walking. Non-standardized } \\
\text { activity }\end{array}$ & $\begin{array}{l}\text { As compared to a non-NE location, } \\
\text { walking in a NE was associated with } \\
\text { improvements of mood and anxiety. }\end{array}$ \\
\hline $\begin{array}{l}\text { Mowen et al. } \\
\text { (2007) [74] }\end{array}$ & 1,515 older adults & $\begin{array}{l}\text { Cross-sectional study with } \\
\text { recruitment of subjects on different } \\
\text { sites. }\end{array}$ & $\begin{array}{l}\text { Availability of urban parks. } \\
\text { Objective measure }\end{array}$ & $\begin{array}{l}\text { PA 'status' (i.e. sedentary/ } \\
\text { active). Self-reported }\end{array}$ & $\begin{array}{l}\text { Proximity to NEs was associated with } \\
\text { more frequent visits to NEs and PA. } \\
\text { The duration of visits which was longer } \\
\text { in subjects living farther away, was not } \\
\text { associated with PA. }\end{array}$ \\
\hline
\end{tabular}


Table 1 Summary of papers included that report original research (Continued)

\begin{tabular}{|c|c|c|c|c|c|}
\hline $\begin{array}{l}\text { Mytton et al. } \\
\text { (2012) [106] }\end{array}$ & 54,296 adults & $\begin{array}{l}\text { Cross-sectional study. Cluster } \\
\text { sampling with selection of } \\
\text { respondents to be representative } \\
\text { of national population. }\end{array}$ & $\begin{array}{l}\text { Availability of nature elements } \\
\text { and green-spaces within the } \\
\text { neighbourhood. Objective } \\
\text { measure }\end{array}$ & $\begin{array}{l}\text { General PA and specific } \\
\text { outdoor PA. Self-reported }\end{array}$ & $\begin{array}{l}\text { Residing in neighbourhood with greater } \\
\text { availability of NEs was a predictor of } \\
\text { meeting recommended levels of PA, } \\
\text { although this association was not } \\
\text { explained by type of PA typically taking } \\
\text { place in NE. }\end{array}$ \\
\hline $\begin{array}{l}\text { Nelson \& Woods } \\
\text { (2010) [81] }\end{array}$ & 2,159 adolescents & $\begin{array}{l}\text { Cross-sectional study. Sampling } \\
\text { technique not described. }\end{array}$ & $\begin{array}{l}\text { Presence of natural elements } \\
\text { along the way to/from school. } \\
\text { Self-reported }\end{array}$ & $\begin{array}{l}\text { Active commuting to school. } \\
\text { Self-reported }\end{array}$ & $\begin{array}{l}\text { Among other characteristics of the } \\
\text { physical environment, there were some } \\
\text { associations NEs and PA, although } \\
\text { mixed results were found. Different } \\
\text { patterns were observed across genders. }\end{array}$ \\
\hline $\begin{array}{l}\text { Orsega-Smith et al. } \\
\text { (2004) [58] }\end{array}$ & $\begin{array}{l}100 \text { older adult users of the } \\
\text { district parks }\end{array}$ & $\begin{array}{l}\text { Cross-sectional study. Onsite } \\
\text { recruitment. }\end{array}$ & Use of urban parks. Self-reported & $\begin{array}{l}\text { Park based PA 'status' } \\
\text { (sedentary/active). } \\
\text { Self-reported }\end{array}$ & $\begin{array}{l}\text { An indirect effect, although weak, of } \\
\text { NE-based leisure on stress and health } \\
\text { was observed. The relationship between } \\
\text { NE-use, PA and stress was not clear. }\end{array}$ \\
\hline Park et al. (2010) [47] & 280 young males overall & $\begin{array}{l}\text { Multiple experimental trials, with } \\
\text { pre-test measurements and } \\
\text { counterbalanced cross-over design. } \\
\text { Random allocation (method not } \\
\text { described). }\end{array}$ & $\begin{array}{l}\text { Forest environment. Standardized } \\
\text { setting }\end{array}$ & Walking. Self-reported & $\begin{array}{l}\text { As compared to urban environments, } \\
\text { being in a NE was associated with an } \\
\text { improvement of mood and physiological } \\
\text { indicators of stress such as heart rate, } \\
\text { blood pressure, salivary cortisol and } \\
\text { indicators of cardiac autonomic control }\end{array}$ \\
\hline Pate et al. (2008) [82] & 1,506 girls & $\begin{array}{l}\text { Cross-sectional study. Subjects } \\
\text { recruited in schools (all students } \\
\text { invited), which were chosen with } \\
\text { the goal of providing balanced } \\
\text { sample. }\end{array}$ & $\begin{array}{l}\text { Availability of parks within the } \\
\text { neighbourhood. Objective measure }\end{array}$ & $\begin{array}{l}\text { Moderate and vigorous PA. } \\
\text { Self-reported }\end{array}$ & $\begin{array}{l}\text { Along with other PA/recreational } \\
\text { facilities, availability of NEs was } \\
\text { positively associated with girls' } \\
\text { participation in PA, although } \\
\text { social-gradients (based on ethnicity) } \\
\text { were observed. }\end{array}$ \\
\hline $\begin{array}{l}\text { Pretty et al. } \\
\text { (2005) [45] }\end{array}$ & 100 adults & $\begin{array}{l}\text { Experimental trial, with pre-test } \\
\text { measurements and between-subjects } \\
\text { design (four treatments and a } \\
\text { control). Random allocation } \\
\text { (method not described). }\end{array}$ & $\begin{array}{l}\text { Exposure to images of NEs on a } \\
\text { screen. Standardized setting }\end{array}$ & $\begin{array}{l}\text { Light-intensity treadmill } \\
\text { exercise. Self-reported }\end{array}$ & $\begin{array}{l}\text { PA whilst viewing images of pleasant } \\
\text { NEs was associated with reduced blood } \\
\text { pressure, and improvements in } \\
\text { self-esteem and mood profile, as } \\
\text { compared with PA whilst viewing } \\
\text { scenes of built environment. Images } \\
\text { of unpleasant NEs had the most } \\
\text { dramatic effect on psychological } \\
\text { responses to PA. }\end{array}$ \\
\hline $\begin{array}{l}\text { Pretty et al. } \\
\text { (2007) [46] }\end{array}$ & 263 adults & $\begin{array}{l}\text { Quasi-experimental, with pre-test } \\
\text { measurements. Cluster sampling } \\
\text { design used to select random } \\
\text { sample of cases. }\end{array}$ & $\begin{array}{l}\text { Different setting for 'green-exercise'/ } \\
\text { outdoor recreations activities in the } \\
\text { countryside. Standardized setting }\end{array}$ & $\begin{array}{l}\text { Different 'green-exercise' } \\
\text { (PA in natural environment) } \\
\text { e.g. walking in NE, horse- } \\
\text { riding, and fishing, canal } \\
\text { boating and conservation } \\
\text { activities. Existing interventions }\end{array}$ & $\begin{array}{l}\text { Experiences of green exercises were } \\
\text { associated with improved mood and } \\
\text { self-esteem. }\end{array}$ \\
\hline
\end{tabular}


Table 1 Summary of papers included that report original research (Continued)

\begin{tabular}{llll}
\hline Prince et al. & 3,883 adults & $\begin{array}{l}\text { Cross sectional study. Random digit } \\
\text { dialled phone survey, applying }\end{array}$ & $\begin{array}{l}\text { Availability of urban green-spaces } \\
\text { and parks within the }\end{array}$ \\
standard survey weights. & Geighbourhood. Objective measure & na. Self-reported
\end{tabular}

$\begin{array}{ll}\begin{array}{l}\text { dialled phone survey, applying } \\ \text { standard survey weights. }\end{array} & \text { and parks within the } \\ & \text { neighbourhood. Objective measure }\end{array}$

Prince et al.
(2012) [71]
R,727 adults
Rhodes et al. $\quad 315$ adults
(2006) [31]

(2006) [31]

adults

Richardson et al.

(2013) [107]

Ries et al.

(2009) [66]

Rodriguez et al.

(2012) [108]

Ryan et al.

(2010) [49]

Scott \& Jackson

(1996) [67]
12,488 youth and adults

329 adolescents (predominantly Afro-American)

293 adolescent girls

66 young adults (study 2 )

1,054 adults
Cross sectional study. Random digit Availability of urban greendialled phone survey, applying spaces and parks within the standard survey weights. neighbourhood. Objective measure

Cross sectional study using random Availability of attractive natural sampling. sight within the neighbourhood. Self-reported

Cross-sectional study. Sampling design not described.

Cross-sectional study. Nonrandomized recruitment among two schools.

Prospective cohort study. Recruitment among from a previous study.

Availability of vegetation and neighbourhood. Objective measure (national databases) Availability of urban parks within the neighbourhood. Objective

Availability of urban parks within the neighbourhood. Objective measure

Experience of PA in a NE.

Experimental trial, with pre-test measurements and betweenStandardized setting

(method not described).

Cross-sectional. Random digit dialled phone survey.
Use of different types of public parks. Self-reported green-spaces within the and self-reported measures

subjects design. Random allocation
No associations or even some negative ones were found between availability of NE and PA Association between PA of and food environment, social cohesion socio-economic status of the neighbourhood and were observed. Different patterns across genders were observed.

Leisure time PA. Self-reported There was some association between availability of NEs and PA. Associations were observed also for food environment, crime and season with different patterns across genders.

Walking. Self-reported

Theory of planned behaviour [28] efficiently predicted the

environment-walking relationship, with NEs and land-use-mix predicting PA via affective and instrumenta attitudes and, to a lesser extent by subjective norms. Perceived behavioural subjective norms. Perceived behavioura
control did not relevantly weighted in control did
the model.

Moderate to vigorous PA. Self-reported

Availability of NEs was associated with probability to meet recommended PA levels, and reduced risk for poor mental health and cardiovascular diseases.

General PA and park-based PA. Self-reported and measured by accelerometry

Associations between the availability of NEs and PA were observed. Use of NEs by peers, age, gender and ethnicity/race also influenced the NE-PA relationship.

Moderate to vigorous PA. Accelerometry and GPS

$\mathrm{NE}$, along with presence of schools and population density, was positively associated with PA. Road length and number of food outlets was negatively associated with PA.

Walking. Standardized activity Walking in a NE had greater impacts on subjective vitality than walking in an interesting and varied indoor setting.

Park visitation. Self-reported

Lack of time' was the most commonly reported reason for not visiting NES. Older women were less likely to visit parks because of fear of crime, lack of companionship and poor health. Improvement of programming and information would encourage more information
visits to NEs. 
Table 1 Summary of papers included that report original research (Continued)

\begin{tabular}{|c|c|c|c|c|c|}
\hline $\begin{array}{l}\text { Sharpe et al. } \\
\text { (2004) [3] }\end{array}$ & 1,936 adults & $\begin{array}{l}\text { Cross-sectional. Random digit } \\
\text { dialled phone survey. }\end{array}$ & $\begin{array}{l}\text { Availability and use of parks and } \\
\text { other outdoor recreations facilities } \\
\text { (e.g. trails and routes for walking } \\
\text { and cycling). Self-reported }\end{array}$ & $\begin{array}{l}\text { Moderate to vigorous PA. } \\
\text { Self-reported }\end{array}$ & $\begin{array}{l}\text { Among other environmental and policy } \\
\text { factors, use of NEs was associated with } \\
\text { PA. However, knowledge and quality } \\
\text { of the infrastructure were important } \\
\text { factors in determining the use of NEs } \\
\text { for PA purposes. }\end{array}$ \\
\hline $\begin{array}{l}\text { Shores \& West } \\
\text { (2009) [88] }\end{array}$ & 139 young adults & $\begin{array}{l}\text { Observational study using } \\
\text { convenience sample (students } \\
\text { recruited during classes). }\end{array}$ & $\begin{array}{l}\text { Perception of public parks as a } \\
\text { source of 'leisure' ("activity } \\
\text { enjoyable for its own sake"). } \\
\text { Self-reported }\end{array}$ & Leisure time PA. Self-reported & $\begin{array}{l}\text { Most of PA perceived as 'leisure' was } \\
\text { carried out in private fitness centres } \\
\text { and dance clubs. NEs were only a small } \\
\text { source of the leisure-time PA. } \\
\text { Companionship and sociality appear } \\
\text { to be important factors for engaging } \\
\text { in leisure PA. }\end{array}$ \\
\hline $\begin{array}{l}\text { Shores et al. } \\
\text { (2008) [72] }\end{array}$ & 454 older adults & $\begin{array}{l}\text { Cross-sectional study using stratified } \\
\text { random sampling design. }\end{array}$ & $\begin{array}{l}\text { Availability of parks in rural areas. } \\
\text { Self-reported }\end{array}$ & $\begin{array}{l}\text { PA status (active or inactive). } \\
\text { Self-reported }\end{array}$ & $\begin{array}{l}\text { Proximity to NEs was positively } \\
\text { associated with PA. Other important } \\
\text { variables predicting PA were access } \\
\text { to social support, safety and reported } \\
\text { ability to walk to a local park. }\end{array}$ \\
\hline $\begin{array}{l}\text { Stigsdotter et al. } \\
\text { (2010) [87] }\end{array}$ & 11,238 adults & $\begin{array}{l}\text { Cross-sectional study using stratified } \\
\text { random sampling design. }\end{array}$ & $\begin{array}{l}\text { Proximity to green-spaces and } \\
\text { motives to visit them. Self-reported }\end{array}$ & $\begin{array}{l}\text { Various PA and outdoor } \\
\text { recreations. Self-reported }\end{array}$ & $\begin{array}{l}\text { PA was reported as the most important } \\
\text { reason for visiting NEs from less stressed } \\
\text { individuals; those who are more stressed } \\
\text { visit NEs to relax, seek for quite places } \\
\text { and engage in social activities. Proximity } \\
\text { to NEs was associated with more } \\
\text { frequent visits to NEs, better quality } \\
\text { of life and less stress. }\end{array}$ \\
\hline $\begin{array}{l}\text { Sugiyama et al. } \\
\text { (2008) [24] }\end{array}$ & 1,895 adults & $\begin{array}{l}\text { Cross-sectional study using cluster } \\
\text { random sampling design. }\end{array}$ & $\begin{array}{l}\text { Perception of availability of nature } \\
\text { and green-spaces within the } \\
\text { neighbourhood (urban). } \\
\text { Self-reported }\end{array}$ & $\begin{array}{l}\text { Leisure and transport walking. } \\
\text { Self-reported }\end{array}$ & $\begin{array}{l}\text { The NE was a predictor of PA and social } \\
\text { factors. PA explained the link between } \\
\text { the NE and physical health. The } \\
\text { relationship between NE and mental } \\
\text { health was only partly accounted } \\
\text { for by PA and social coherence. }\end{array}$ \\
\hline $\begin{array}{l}\text { Thompson et al. } \\
\text { (2012) [27] }\end{array}$ & 25 adults & $\begin{array}{l}\text { Observational exploratory study, } \\
\text { using convenience sampling design. }\end{array}$ & $\begin{array}{l}\text { Availability of green-space within } \\
\text { the neighbourhood (urban). } \\
\text { Self-reported }\end{array}$ & General PA. Self-reported & $\begin{array}{l}\text { Availability of NEs was associated with } \\
\text { less perceived stress and, along with } \\
\text { PA, with better cortisol profiles. A } \\
\text { direct association between availability } \\
\text { of NEs and PA was not found. }\end{array}$ \\
\hline $\begin{array}{l}\text { Toftager et al. } \\
\text { (2011) [109] }\end{array}$ & 21,832 adults & $\begin{array}{l}\text { Cross-sectional study using stratified } \\
\text { random sampling design. }\end{array}$ & $\begin{array}{l}\text { Proximity to green spaces (beach, } \\
\text { seaside, lake, park, urban green } \\
\text { space, forest or other open green } \\
\text { spaces excluding agricultural } \\
\text { fields). Self-reported }\end{array}$ & $\begin{array}{l}\text { Leisure time moderate to } \\
\text { vigorous PA. Self-reported }\end{array}$ & $\begin{array}{l}\text { Proximity to NEs was associated with } \\
\text { more PA. People living closer to NEs } \\
\text { had increased chances in using it for } \\
\text { PA purposes. }\end{array}$ \\
\hline
\end{tabular}


Table 1 Summary of papers included that report original research (Continued)

\begin{tabular}{|c|c|c|c|c|c|}
\hline $\begin{array}{l}\text { Van den Berg \& } \\
\text { Custers, (2011) [54] }\end{array}$ & 30 middle-aged adults & $\begin{array}{l}\text { Experimental trial with between- } \\
\text { subjects design and pre-test } \\
\text { measurements. Random allocation. }\end{array}$ & Experience of gardening activity. & $\begin{array}{l}\text { Gardening. Standardized } \\
\text { activity }\end{array}$ & $\begin{array}{l}\text { After an induced stress, both reading } \\
\text { and gardening were associated with } \\
\text { an improvement in stress parameters } \\
\text { (mood and salivary cortisol), with } \\
\text { greater improvements observed after } \\
\text { gardening. The difference between } \\
\text { the 'stress recovery' interventions was } \\
\text { somewhat weak. }\end{array}$ \\
\hline $\begin{array}{l}\text { Ward Thompson } \\
\text { et al. (2012) [110] }\end{array}$ & 96/61 older adults & $\begin{array}{l}\text { Cross-sectional and longitudinal } \\
\text { cohort / quasi-experimental study, } \\
\text { with pre- and post-intervention } \\
\text { measurements. }\end{array}$ & $\begin{array}{l}\text { Availability of urban parks and } \\
\text { other natural environments. } \\
\text { Self-reported / perceived }\end{array}$ & $\begin{array}{l}\text { General PA \& any outdoor } \\
\text { activity. Self-reported and } \\
\text { measured by accelerometry }\end{array}$ & $\begin{array}{l}\text { Availability of clean and quite NEs with } \\
\text { attractive, barrier-free routes to it was } \\
\text { positively associated with more PA. } \\
\text { No significant change of PA ratings } \\
\text { was found after the neighbourhood } \\
\text { improvement intervention. }\end{array}$ \\
\hline $\begin{array}{l}\text { Wen \& Zang } \\
\text { (2009) [111] }\end{array}$ & 3,530/907 adults & $\begin{array}{l}\text { Multilevel cross sectional study. } \\
\text { Random digit dialled phone survey. }\end{array}$ & $\begin{array}{l}\text { Availability of urban parks within } \\
\text { the neighbourhood. Objective } \\
\text { measure }\end{array}$ & $\begin{array}{l}\text { Exercise behaviour. } \\
\text { Self-reported }\end{array}$ & $\begin{array}{l}\text { Access to NEs was not associated with } \\
\text { PA. Predictors of PA were social capital } \\
\text { and access to restaurants/bars. }\end{array}$ \\
\hline $\begin{array}{l}\text { Wen et al. } \\
\text { (2007) [73] }\end{array}$ & 41,545 adults & $\begin{array}{l}\text { Cross-sectional study. Random digit } \\
\text { dialled phone survey. }\end{array}$ & $\begin{array}{l}\text { Availability of parks/open-spaces } \\
\text { within the neighbourhood. } \\
\text { Self-reported }\end{array}$ & $\begin{array}{l}\text { Leisure and transport walking. } \\
\text { Self-reported }\end{array}$ & $\begin{array}{l}\text { Availability of NEs along with } \\
\text { neighbourhood social cohesion was } \\
\text { positively associated with PA. Individual } \\
\text { socio-demographic and safety did not } \\
\text { have significant effects on PA, while } \\
\text { differences for race/ethnicity were } \\
\text { observed. }\end{array}$ \\
\hline $\begin{array}{l}\text { West et al. } \\
\text { (2012) [112] }\end{array}$ & $\begin{array}{l}\text { Adult respondents within } 67 \\
\text { metropolitan statistical areas }\end{array}$ & $\begin{array}{l}\text { Cross-sectional study using random } \\
\text { sampling design. }\end{array}$ & $\begin{array}{l}\text { Availability of urban parks within } \\
\text { the neighbourhood. Objective } \\
\text { measure }\end{array}$ & $\begin{array}{l}\text { Moderate and vigorous PA. } \\
\text { Self-reported }\end{array}$ & $\begin{array}{l}\text { Availability of NEs was positively } \\
\text { associated with probability of meeting } \\
\text { PA recommendations, and negatively } \\
\text { associated with risk of being } \\
\text { overweight/obese. }\end{array}$ \\
\hline $\begin{array}{l}\text { Wilson et al. } \\
\text { (2011) [86] }\end{array}$ & 10,286 middle-age adults & $\begin{array}{l}\text { Cross sectional study using a } \\
\text { stratified two-stage cluster design. }\end{array}$ & $\begin{array}{l}\text { Availability of different NEs. } \\
\text { Objective and self-reported } \\
\text { measure }\end{array}$ & Walking. Self-reported & $\begin{array}{l}\text { Different NEs had different effects on } \\
\text { PA. E.g. proximity to rivers and coasts } \\
\text { was positively associated, while tree } \\
\text { coverage was negatively associated } \\
\text { and proximity to parks was not } \\
\text { associated. Other environmental factors } \\
\text { also predicted PA. }\end{array}$ \\
\hline $\begin{array}{l}\text { Witten et al. } \\
\text { (2008) [113] }\end{array}$ & 12,529 youths and adults & $\begin{array}{l}\text { Cross-sectional study. Sampling } \\
\text { design not reported. }\end{array}$ & $\begin{array}{l}\text { Availability to different NEs. } \\
\text { Objective measures }\end{array}$ & $\begin{array}{l}\text { Brisk walking, moderate and } \\
\text { vigorous PA. Self-reported }\end{array}$ & $\begin{array}{l}\text { Different NEs had different effects on PA } \\
\text { and BMI. E.g. parks were not associated } \\
\text { with PA, while some associations were } \\
\text { found for beaches/coasts. }\end{array}$ \\
\hline $\begin{array}{l}\text { Yamaguchi et al. } \\
\text { (2006) [62] }\end{array}$ & 15 young males & $\begin{array}{l}\text { Experimental trial, with } \\
\text { counterbalanced cross-over } \\
\text { design (two treatments and } \\
\text { a control). }\end{array}$ & Low threshold exercise in NE. & Walking. Standardized activity & $\begin{array}{l}\text { As compared to urban environment, } \\
\text { PA in NE was associated with an } \\
\text { improved profile of indicators of } \\
\text { sympathetic nervous activity (salivary } \\
\text { amylase). }\end{array}$ \\
\hline
\end{tabular}


Table 2 Summary of papers included that report theoretical studies and literature reviews

\begin{tabular}{lllll}
\hline AUTHORS & NUMBER OF & STUDY DESIGN & EXPERIENCE OF THE NATURAL & TYPE OF PHYSICAL ACTIVITY (PA) \\
& INCLUDED PAPERS & & SUMMARY OF FINDINGS \\
\hline $\begin{array}{l}\text { Bedimo-Rung et al. } \\
\text { (2005) [5] }\end{array}$ & Not reported & $\begin{array}{l}\text { Theoretical paper based on } \\
\text { existing literature. }\end{array}$ & $\begin{array}{l}\text { Availability and perception of urban } \\
\text { parks and other NEs }\end{array}$ & $\begin{array}{l}\text { Park-based activities } \\
\end{array}$ \\
& & & $\begin{array}{l}\text { A conceptual model based on an analysis of } \\
\text { literature depicts how park features, condition, } \\
\text { access, aesthetic, safety and policy might } \\
\text { enhance or undermine physical activity levels } \\
\text { and public health. }\end{array}$
\end{tabular}

Bowler et al. (2010) [10] 24 papers

Systematic review of literature with meta-analysis. Assessment of quality not reported

Experiences in various NEs, including laboratory and outdoor experimental trials settings

Theoretical paper based on Experiences in the wilderness. existing literature.

Theoretical paper based on existing literature.

Systematic review of literature. Assessment of quality not reported

Kaczynski 2 50 papers

Lee \& Maheswaran $\quad 35$ papers (2011) [9]

\section{5 papers}

Systematic review of literature. Assessment of quality was performed and reported.

Availability of NEs, prevalently
urban green spaces

Availability of NEs, preva
urban green spaces

\section{Contributi}

Availability of parks.

\section{General PA, including}

Systematic review of Literature. PA experiences in various settings, Assessment of quality performed including laboratory and outdoor
Thompson Coon et al. 11 papers (2011) [11]

\begin{abstract}
and reported.
\end{abstract} neighbourhood-based PA and active transport, among others

General PA, including neighbourhood-based PA and active transport, among others

Friluftsliv (traditional Scandinavian outdoor recreations)

Various, including laboratory-based experimental trials.
Exposure to the NE whilst engaging in PA is associated with greater health benefits than PA alone, especially for what concerns psychological outputs (e.g. positive emotions and indicators of mental health). Benefits of $P A$ in contact with nature on indicators of physical health, such as blood pressure and cortisol production, remain somehow inconclusive.

Friluftsliv is analysed in relationship with its socio-historical background and underlying physiological mechanisms. Implications for environmental and PA education are discussed. The impact of the NE for human health, including possible motivational mechanisms that may encourage PA, is discussed.

Availability of NEs was generally associated with more PA and health within the community. Parks, trails, and other open spaces had some of the most consistent relationships with PA, when compared with indoor recreation facilities and sport centres.

There are evidences of a positive association between availability of NEs and health via PA. Anyway, the relationship between access to NEs, PA and health is likely to be complex, and yet remain controversial. Methodological challenges and quality of the available studies in this field are discussed.

Compared with PA indoors, PA in NE had greater effects on indicators of mental health and well-being. Methodological challenges and quality of the available studies in this field are discussed. 
Table 3 Analysis of studies included based on constructs of the theory of planned behaviour

\begin{tabular}{|c|c|c|c|c|c|}
\hline $\begin{array}{l}\text { Type of physical activity } \\
\text { output }\end{array}$ & $\begin{array}{l}\text { Overall positive } \\
\text { effects }\end{array}$ & $\begin{array}{l}\text { Partially or moderately } \\
\text { positive effects }{ }^{a}\end{array}$ & $\begin{array}{l}\text { Mixed or no } \\
\text { effects }\end{array}$ & $\begin{array}{l}\text { Overall negative } \\
\text { effects }\end{array}$ & $\begin{array}{l}\text { Study of underlying } \\
\text { mechanism }\end{array}$ \\
\hline \multicolumn{6}{|l|}{ Behavioural beliefs } \\
\hline Psychological states $^{\mathrm{d}}$ & $\begin{array}{l}{[10,11,21,31,40,43,45-49,} \\
51-55,57]\end{array}$ & {$[92,107]$} & {$[41,44,50]$} & & {$[21,31,48]$} \\
\hline Stress relief (psychological) ${ }^{\mathrm{e}}$ & {$[23,31,44,59,87]$} & {$[10,27]$} & [58] & & {$[60]$} \\
\hline Stress relief (physiological) $)^{f}$ & $\begin{array}{l}{[25,27,43,47,61,62]} \\
{[42,43,55]}\end{array}$ & {$[10,40,45,58][54]$} & {$[42,44]$} & & [25] \\
\hline Instrumental beliefs & {$[65,91]$} & [64] & & & {$[31,63,89,91]$} \\
\hline $\begin{array}{l}\text { Feelings about/interest in } \\
\text { nature }\end{array}$ & {$[53,91]$} & & & & {$[53,59,67,91]$} \\
\hline \multicolumn{6}{|l|}{ Normative and control beliefs } \\
\hline $\begin{array}{l}\text { Perceived behavioural control/ } \\
\text { self-efficacy }\end{array}$ & & & & & {$[31,32,56,69,88]$} \\
\hline Social support & {$[23,24,87,91]$} & & & [59] & {$[24,63,66,68,70-73,88,111]$} \\
\hline Personal barriers & & & & & {$[9,59,67,70-72,75-82,88]$} \\
\hline Environmental barriers & & & & & $\begin{array}{l}{[3,9,23,24,31,50,58,63,64,} \\
66-75,77,78,80,81,83-87, \\
90,93,96,97,100,101,103 \\
104,106,109,110,113]\end{array}$ \\
\hline \multicolumn{6}{|l|}{ Behavioural intention } \\
\hline $\begin{array}{l}\text { Intention to visit NEs or } \\
\text { engage in PA }\end{array}$ & {$[31]$} & {$[67,102]$} & & & {$[31,32]$} \\
\hline Motives for visiting NEs & [109] & & & & {$[67,87,91]$} \\
\hline Likeability/Preference & {$[40,44,50]$} & & & & {$[5,12,14]$} \\
\hline \multicolumn{6}{|l|}{ PA behaviours } \\
\hline General PA & $\begin{array}{l}{[23,24,31,56,63,65,72,73} \\
75,78,79,83,84,87,92,94 \\
95,101,102,105-110,112]\end{array}$ & $\begin{array}{l}{[3,8,9,64,66,68,69,71,77} \\
80,82,88,93,113]\end{array}$ & $\begin{array}{l}{[27,70,81,86,96-98} \\
103,111]\end{array}$ & {$[100]$} & {$[31,104]$} \\
\hline NE-based PA & {$[63,65,76,79,85,99,109]$} & {$[64,66,69]$} & {$[58,74,103,106]$} & & {$[5,12,14,32,59,99]$} \\
\hline
\end{tabular}

Theoretical and literature studies are highlighted in bold.

${ }^{(a)}$ Significance was of moderate extent (e.g. other factors were more relevant), or achieved for only part of PA outputs or population subgroup.

${ }^{(b)}$ The analysis returned no effects or mixed effects, i.e. some positive and some negative, in relation to different study variables or population subgroups.

${ }^{(c)}$ The study describes mechanisms underlying the effects of NE on the specific variable.

${ }^{(d)}$ Mood, self-esteem, vitalization, positive affect, happiness, and mental health parameters.

(e) Perceived environment for restoration, self-reported stress.

${ }^{(f)}$ Stress hormones, blood pressure, other indicators of allostatic load (e.g. salivary amylase and heart rate variability, and brain-wave activity).

[31,63-65] and feelings about nature [53], were used either as dependent or independent variables, or included in mediation models. Furthermore, we identified a number of normative beliefs $[31,32,63,66-68]$ and control beliefs $[23,24,31,32,56,59,63,66-86]$, which were also widely used as controlling/moderating variables.

Under the intention construct, we classified outcomes that included intention to walk [31] or engage in outdoor recreations [32] and 'likeability/preference' (i.e. whether the participants preferred to engage in PA at either an NE or a control environment) [40,44,50]. Motives/reasons for visiting NEs [67,87-91] were also considered in relation to intention. For PA behaviour we classified outcomes referring to PA measurements as a dependent variable in relation to NEs, studied only in observational studies [3,23,27,31,32,56,59,63-66,68-88,90,92-113], whereas in experimental studies PA was set as an intervention. In several studies the behavioural outcome concerned general levels of PA, leisure-time PA or moderate-to-vigorous PA. A number of studies measured specific types of PA that take place in NEs, such as walking, cycling, gardening and NE-based PA [24,31, 32,59,63-66,68,69,74-80,85,90,93,97,99-101,103,104,106, $109,110]$. Most of the studies used self-reported measurements of PA, whereas only a few studies used objective measurements such as actigraphy $[66,108,110]$ or direct observation $[76,85]$.

In the reviewed studies, various NEs were examined, including forests and national parks, and urban green spaces or the presence of elements of nature within the neighbourhood. NEs consisted mainly of vegetation (e.g. trees, gardens or parks), although several studies also 
included water (e.g. lakes, beaches and sea views). Four experimental studies used 'virtual' NEs, displaying images of them $[21,45,53,60]$. Most of the studies used objective assessments of the NE. However, some studies used self-reported or perceptions of NEs [3,24,31,68, $72,73,75,77,102,104,109,110]$, and others a combination of perceived and objective measurements $[63,66,74,85]$. In several studies, NEs were defined as 'parks' without explicit reference to the amount or type of nature contained within it $[3,65,66,71-74,76,78-80,82,84,93,99$, $100,108,111,112]$. Therefore, it may be assumed that in these studies NEs were mixed with different types of built environments such as playgrounds and sports fields. In two experimental studies, NEs referred to outdoor space surrounding a college campus $[40,41]$.

With regard to the specific types of PA (including studies in which PA was not the dependent variable), of the studies reviewed, general PA levels and walking were the types most represented [22,24,25,31,42,43,47, 49,51-53,55,60-62,64,68,73,75,77,78,80,86,89,90,93,100, $101,103,104,113]$. Other PA types included running/ jogging [40,41,44,50,63], NE-based PA [23,59,64-66,69, $76,79,85]$ and outdoor recreation [32,46,67,87,91,106,110]. In two studies, gardening was also used as a dependent variable [103] or intervention [50].

\section{Underlying TPB beliefs \\ Behavioural beliefs}

Positive psychological states In line with existing reviews $[10,11]$, we found that $\mathrm{PA}$ in touch with nature was quite consistently associated with greater benefits in terms of positive emotions and psychological states, compared with PA in the indoor and/or urban setting. Improvements in mood and positive affect were shown in case studies $[42,46]$, as well as in controlled trials, in which experiences in NEs were compared with those in urban settings $[43,47,51-53,55,61]$ or indoors $[40,42,49,53,60]$, and also in laboratory studies where participants exercised on a treadmill while images of NEs or built environments were displayed on a screen $[21,45]$. Positive effects were also found on participants' self-esteem [45,46,48], happiness [42] and indicators of mental health [57], again with positive effects shown for experiences in a NE. Furthermore, it was found that affective beliefs such as enjoyment $[31,56]$ influenced the relationship between perceived availability of NEs and number of people engaging in leisure PA. In particular, positive effects on psychological states were found when participants were engaged in 'light' PA such as walking $[42,43,45,47,49,51-53,55,60]$.

Whether the intensity of the PA can impact the positive psychological states associated with exposure to nature appears to be somewhat controversial. In a meta-analysis investigating the dose-response of psychological responses to PA in NEs, it was found that improvements in selfesteem decrease with growing PA intensity, whereas effects on mood were depicted better as a ' $U$ '-shaped doseresponse curve, with greater improvements for light or moderate-to-vigorous PA intensity [48]. A dose-response was observed for the duration of exposure to PA in NEs, with shorter exposure (5 minutes) showing the greatest effects [48]. Some studies on running $[41,44,50]$ did not find positive effects for NEs on participant mood. However, it was observed that a perception of lack of safety may have influenced the mood when running in NEs [50], and some limitations were the result of small sample size [44]. On the other hand, one study on running [40], and studies using other types of outdoor recreation [46] that are more intensive or complex than walking, showed positive effects on psychological states.

\section{Stress relief}

Individuals who had higher stress ratings, reported visiting NEs to 'relax', 'seek quiet places' and 'get away from the usual demands of life' $[87,91]$; they tended to stay longer when they visited the NE [58]. The NE is perceived as providing greater potential for restoration, compared with indoor exercise facilities and urban settings $[42-44,59,60]$, and apparently engaging in vigorous PA does not reduce such a perception of the environment. In fact, NEs were assigned greater potential for restoration than other environments, irrespective of whether the participants were walking at a comfortable pace $[22,25,42,43,45,47,49,62]$, running $[40,44]$ or engaging in other forms of PA and recreation [23,27,59]. In a recent study using a mobile EEG, while participants walked in NEs after an induced stressor, researchers were able to show that brain wave activity indicated stress-relief effects in accordance with the Kaplans' ART [25]. Moreover, access to NEs and PA was associated with reduced self-reported stress and biological indicators of stress $[23,27,58,87]$, although the interrelationships of NE, PA and stress were not fully explained. It has been suggested that PA may play an intermediate role, indirectly eliciting stress relief through social support $[23,58,87]$. However, in an exploratory study, a direct effect of PA on stress was observed, parallel to but independent of the NE [27]. In addition, several experimental studies showed positive effects on different indicators of psychosomatic stress when PA was in an NE compared with PA in other environments (i.e. indoor or urban settings) $[40,47,54,55,62]$, although systematic synthesis indicated that, overall, the effects of PA in NEs on stress hormones remain somewhat inconclusive $[10,11]$. Mixed results have been reported with regard to blood pressure, because some studies reported positive effects after experiences of PA in NEs $[43,45,47,61]$ whereas others found no effects [42], or even 
negative effects when PA was associated with unpleasant images of NEs [45].

\section{Instrumental beliefs}

Instrumental beliefs, such as expected health benefits of PA, are likely to influence participation in PA, irrespective of the environmental conditions. Instrumental beliefs were found to mediate the environment-walking relationship [31]. Having health goals, along with using environments that support walking, were found to sustain walking routines [89]. However, attitudes towards health seem to have a small effect on mediating the relationship between the availability of NEs and neighbourhoodbased PA behaviour [63]. On the other hand, some studies suggest that NEs may impact people's attitudes toward PA via instrumental beliefs. For instance, there was a strong agreement among people living near to parks that availability of neighbourhood NEs is a benefit, and such a belief was associated with higher general and NE-based PA [65]. 'Mental and physical health' was found to be an important benefit reported by visitors to NEs [91], and proximity to green spaces was positively associated with visiting NEs for 'exercise and keep in shape' [109]. Moreover, NE-based interventions have been reported to have some positive impacts on enhancing awareness of the benefits of PA for health [64].

\section{Feelings about nature}

Some traditional/philosophical approaches to outdoor activities refer to the feelings of 'commitment to nature, which are associated with the perceived need to be in touch with nature and the wilderness [12]. Increases in connectedness to nature (a measure of individuals' trait levels of feeling emotionally connected to the natural world) were found to mediate the positive psychological states in response to experiences in nature [53]. Compatibility (the perceived restorative quality described in Kaplans' ART that quantifies to what extent an environment is compatible with the individual's inclinations or preferences) predicted the frequency of exercising in the NE [59]. Accordingly, 'enjoy nature' was an important benefit reported by visitors to NEs [91], whereas the lack of interest in engaging in NE-based recreation (e.g. 'pursue recreation in other areas' and 'don't like to participate in nature or outdoor recreation') was reported as a recurrent reason by people who do not visit NEs [67]. Although we identified few studies taking into account how an individual's feelings about nature impact the relationship between PA behaviours and positive psychological responses to experiences in nature $[53,59]$, overall the findings indicate that individuals with stronger feelings about nature may be more predisposed to visit available NEs. Feelings about nature can represent a motivational factor for engaging in outdoor recreations, which then allow a person to be in close touch with nature. On the other hand, in activities such as neighbourhood walking or jogging, the individual-NE relationship is more 'superficial', with the NE providing a quiet and aesthetically pleasing environment for the individual [31,63]. Here instrumental beliefs such as health and aesthetic goals may play an important role. Interestingly, some studies reported that experiences in nature can increase people's connectedness to nature [53]. Unfortunately, implications for this effect on PA behaviour, i.e. whether interventions aiming to increase people's feelings about nature increase their predisposition to use available NEs for PA purposes, have not been explored.

\section{Normative beliefs}

To what extent normative beliefs influence PA behaviours in NEs have revealed mixed results. For instance, subjective norm was found to mediate the association between perceived availability of NEs in the neighbourhood and walking [31], whereas no effect predicted participation in outdoor recreation [32]. PA is an opportunity to meet friends and spend time with them, so an individual's choice to engage in PA, as well as its location, can be subjected to influences by friends' perceived expectations [88]. Companionship or having friends to engage in PA with has been identified as a factor influencing participation in leisure PA, as well as the use of NEs for PA purposes [66-68]. For example, people who choose to use a NE as an arena for PA report less expected social benefits, while their choice is weighted more by the individual's environmental compatibility (see 'Feelings about nature' above) [59]. It was found that college students spent most of their leisure PA in fitness centres and dance clubs, which are meeting points for school mates and friends, whereas NE-based PA was less endorsed [88]. Similarly, individuals who envisage companionship as a motivational strategy engaged in less neighbour-based PA such as walking, although they engaged more in other forms of PA [89].

\section{Control beliefs}

Perceived behavioural control and self-efficacy (conceptually similar to perceived behavioural control [28]) are known to influence participation in PA, irrespective of the environmental conditions. However, they have not been found to significantly mediate the relationship between availability of NEs in the neighbourhood and PA $[31,56,69]$. It has been suggested that the environment might have a more 'direct' effect on behaviours through unknown mechanisms that strengthen the conversion of intention to behaviour [56]. For instance, the intention to engage in moderate PA, such as walking, may be influenced more by attitude than perceived behavioural control [31]. Although the stronger effect of attitude was 
evidenced only on neighbourhood-based PA (such as walking or jogging), perceived behavioural control had a stronger effect in predicting participation in outdoor recreation in activities such as lake canoeing/kayaking, orienteering and archery [32]. Perceived ability to walk to local NEs was also found to be a predictor of PA among older adults living in rural areas [88].

Although perceived behavioural control may not mediate the relationship between availability of NEs and certain types of PA [31,56], actual behavioural control, as an expression of individual or environmental barriers, could possibly have a direct impact on the relationship. In fact, as previously outlined [5,9], several studies concluded that the characteristics of the individual or environment impact the relationship between NEs and PA. In particular, individual characteristics such as gender, age and family status are likely to influence perceived behavioural control or reflect subjective norms. For instance, some girls and women perceive walking or running alone in NEs as dangerous and/or not socially convenient $[50,77,81]$.

\section{Individual barriers}

The most commonly reported reason not to visit NEs was 'lack of time' followed by personal barriers (e.g. poor health) [67]. However, different studies found that age $[48,67,79,103]$ and gender $[48,66,67,70,71,76,77,79,81,83,92]$ also affected the way NEs impact on PA behaviours, although mixed results were reported. For example, some studies suggest that NEs may encourage PA, especially among girls and women $[70,71,79,83]$, whereas others reported that women perceive more barriers in NEs than men do, especially in relation to perceived safety $[50,67,76,81]$. Greater effects by the presence of NE on psychological states [48] and PA behaviour [79] were found in younger and older individuals, as compared to middle age groups. However, these findings were not always confirmed, possibly due to other factors such as perceived safety [67]. Differences across age-groups were also associated with the type of PA [103]. The effects of socioeconomic status and race/ethnicity on the way NEs promote PA appear to be more consistent, with lower socioeconomic status and being a member of an ethnic minority seen as barriers to the use of NEs for PA purposes $[63,66,68,70,80,82]$. Perceived safety is also consistently found to be an important factor influencing PA and visits to NEs [66-68,72,75,77,78,81,90], although not in all studies [73,97].

\section{Environmental barriers}

Environmental barriers such as traffic $[78,97,101]$, gradient of the pavement $[78,84,101,104]$, poor lighting $[86,101]$, lack of safety $[66-68,71,72,75,77,81,100]$ and noise/air pollution $[75,110]$ were found to have negative influences on PA behaviours and possibly to hinder visits to NEs. On the contrary, street connectivity $[78,86]$, land-use mix [31,81] and destinations available within walking distance $[68,73,101]$ are environmental characteristics that promoted PA, irrespective of the presence/ absence of NEs. The social environment (e.g. social cohesion within the neighbourhood) was also consistently found to influence PA behaviour [63,66,67,70,72,90,111], possibly to a greater extent than the availability of NEs $[72,111]$. On the other hand, findings suggest that NEs can also play a reverse role, providing individuals with social benefits and opportunities to engage in social activities $[23,24,58,66,74,87,91]$. Differences between rural and urban environments have been identified, with the NE-PA relationship being stronger for people living in urban rather than rural areas $[63,96,103,106]$, probably due to differences in land-use mix and connectivity.

The subjective perceptions of environment also operate as barriers and appear to be a stronger predictor of PA $[65,104]$. For example, distance to NEs from people's residences was a barrier to visits to NEs and their use for PA purposes [69,72,74,77,80,85-87,93,109,113]. Though, perceived and objective walking distances from NEs correlated poorly with each other, and self-efficacy did not explain the mismatch [69]. An 'incorrect' perception of the distance to NEs might be due to lack of information; in fact 'lack of information/knowledge' was found to be an important reason for not visiting NEs [3], whereas improved information was self-reported as a strategy that would encourage people to visit NEs and engage in PA $[64,67]$.

Although there is overwhelming agreement about environmental barriers hampering the use of NEs for PA purposes [5,9], to date little has been said about the specific characteristics of NEs that promote active living [5]. Some studies suggest that those that provide a greater variation between nature and built elements have greater effects on PA promotion $[78,83,85]$. For example, extensive tree coverage discouraged individuals from engaging in PA [86]. On the contrary, naturalistic urban parks furnished with paved paths and features supporting PA were found to be a strong predictor of park visits and PA [85]. Neighbourhoods with well-maintained pavements that offer attractive views of nature appeared to be an important element in encouraging neighbourhood-based PA such as walking [31]. In particular, views of parks/gardens $[31,63,69,81,90,101,110]$ and the seaside $[81,90]$, as well as the presence of trees $[75,81,90,101,104]$, were consistently found to encourage PA, even for a practical reason such as providing shelter from the sun [104].

\section{Intention}

The 'presence of attractive nature views' in the neighbourhood was found to predict walking via subjective 
norm, attitudes and intention, with affective beliefs ('feeling good' and 'stress relief') providing stronger prediction than instrumental beliefs (e.g. health-related benefits) [31]. Intention was also found to predict participation in outdoor recreations such as canoeing/kayaking, orienteering and archery [32].

Unfortunately we found only two studies investigating whether intention predicts PA behaviour in NE, whereas other studies investigated the explicit reasons and motives for visiting NEs and how these motives supported PA. 'Enjoying nature/getting fresh air' and 'reducing stress' were reported as the most common reasons for visiting NEs, especially among individuals who reported higher stress levels [87,91]. 'Exercise and staying in shape' was also reported as an important reason for visiting NEs $[87,109]$, especially among people living closer to them [109]. Experimental studies found that NEs were perceived as more 'likeable/preferable' by runners compared with indoor or urban settings [40,44], and 'neighbour nature' was reported as an important environmental factor helping people sustain walking routines $[89,90]$. Furthermore, respondents have reported that they would visit NEs if available near their homes $[67,102]$.

\section{Physical activity behaviour}

In an attempt to answer the question of whether NEs can encourage active living, a large number of crosssectional studies tried to define the relationship between access to green areas and PA rates. Most of the studies indicate that availability of NEs within the living environment is generally associated with more PA [23,31, $63,65,72-76,79,83-85,87,92,94,95,99,101,105,107-110,112]$, although some yield partial associations or small effect sizes $[3,66,68,71,77,80,82,93,106,113]$. There are, however, studies that showed no association between NEs and PA $[27,96-98,111]$ or even a negative association [100]. Other studies found mixed effects, with differences relating to the type of NE $[81,86]$, type of PA [103] and participants' gender $[70,71,81]$. However, many studies have not accounted for whether respondents with more accessibility to NEs actually engaged in more PA in them, while measuring total PA levels as a dependent variable. In the attempt to have better disclosure of the NE-PA relationship, some studies have specifically investigated possible associations between availability of NEs and NE-based PA, and most of these studies did find positive associations [63-66,69,76,79,85,99,109]. Yet some studies reported unclear $[58,74]$ or mixed results $[103,106]$, especially with respect to the specific type of PA studied.

A question was raised about the possibility of a selfselection phenomenon: Do individuals who are already physically active choose to live in areas where more PA opportunities exist? Only two studies addressed this question and excluded the effect of self-selection, concluding that NEs can actually encourage people to embrace active lifestyles $[56,99]$. As availability of NEs within a living environment appears to promote neighbourhoodbased PA, another question was raised: Do visits to NEs such as parks and green spaces make a relevant contribution to overall PA levels? Although visits to NEs do not necessarily imply engagement in PA [5], visits to NEs even for 'sedentary' purposes can lead to increased PA, because people who visited NEs more often were more likely to meet the minimum recommended levels of PA $[3,76,102]$.

\section{Integration}

According to the reviewed studies and in light of the $\mathrm{TPB}$, evidence supported the theory that availability of NEs can increase motivation to engage in PA via intention and affective beliefs such as positive emotions and stress relief. Positive PA experiences can enhance attitudes toward PA and perceived behavioural control, leading to firmer intentions to engage in PA. Individual and environmental barriers, as expressions of one's actual behavioural control and social support, influence the process via perceived behavioural control and subjective norm. Instrumental beliefs such as expected health benefits and the desire to enjoy nature also impact the process via behavioural attitudes. The conceptual model that emerged (Figure 2) is depicted as a double circular one in order to portray the two different roles that NEs have as PA arenas.

On the one hand, elements of nature integrated within people's living environments, such as attractive natural views in the neighbourhood, can encourage active living through mode of transport and leisure PA such as walking, cycling or jogging. On the other hand, NEs are arenas for outdoor recreations that imply a closer relationship between the individual and the NE itself, such as hiking, gardening, fishing, etc. In both cases, experiences in NEs influence individual attitudes toward PA, and strengthen motivation to embrace an active lifestyle, whereas personal and environmental factors either positively or negatively influence the process. In both circles, visits to NEs and their use for PA purposes are mediated by intention. The two circles differ not only in the type of PA and PA-NE relationship involved, but also in the way that other factors influence one's intention to use NEs for PA purposes. For example, attitudes towards outdoor recreation are likely to be influenced by feeling about nature, and the intention to participate in outdoor recreation is impacted more by perceived behavioural control. However, attitudes towards neighbourhood-based PA such as walking or jogging appear to be influenced more by instrumental beliefs such as expected health and aesthetic benefits, and the intention to engage in such 
activities is subjected less to perceived behavioural control, while it appears to be more attitude-driven.

\section{Discussion}

The natural environment is a resource promoting health and wellbeing through reduction of stress and risk for poor mental health $[10,11,26,57]$, and its relevance in land-use planning has been advocated [6,7]. Some evidence indicates also that visits to NEs can reduce the risk of chronic diseases such as cancer [22] and cardiovascular diseases [114]. Furthermore, availability of NEs within the living environment can play a significant role in promoting PA, both providing the opportunity to engage in PA and sustaining active living $[5,14,31,89,90]$. Active lifestyles, characterized by more low-threshold PA in everyday life routines and less sedentary behaviour (e.g. watching TV), have been shown to have the potential to impact greatly on health, even when not engaging in a purposeful exercise programme [115,116]. Therefore, interventions that encourage active living among the population, through both mode of transport and leisure activities, can have a great impact on promoting health. Walking and cycling are an important source of aerobic PA for many. However, the WHO also recommends that: 'Muscle-strengthening activities should be done involving major muscle groups on two or more days a week' [1]. It is therefore important that interventions pay attention to promote a variety of PA that offers greater potential for muscle conditioning through whole-body involvement. Different outdoor recreations, including gardening and use of fitness trails, can provide such physical conditioning. However, promotion of such types of PA can be challenging because of greater personal barriers (i.e. self-efficacy or perceived behavioural control). Interventions must therefore act at a multilevel scale, targeting individuals as well as the living environment to induce behavioural changes in the population [2]. Such a multilevel approach includes both infrastructural intervention and social campaigns. The identification of environmental preferences and belief-based targets for the promotion of PA are an important stage for effective interventions. Throughout this integrative study, it has been shown how NEs can support motivation to embrace and sustain an active lifestyle, and underlying beliefs, possible barriers to PA and preferred environmental characteristics were identified. The environmentally and belief-based targets identified in this paper should be used in land-use planning as well as in social campaigns promoting active living through messages to the community.

\section{Strengths and limitations of the study}

To date, this study is the most extensive review of literature about the health effects of PA in NEs, presenting a novel and extensive analysis of motivational processes underlying the relationship between experiences of nature and PA behaviours. We used systematic methodologies to identify and analyse relevant papers and the TPB to guide this synthesis. The TPB was chosen because it has been previously used to explain behaviour with regard to PA and NEs [31,32], and it has been proposed as a valuable model to explain the links between environmental cognitions and PA [4]. These elements make this study a robust one compared with other reviews of literature attempting to explain how NEs can improve motivation to engage in PA $[12,14]$. Nevertheless, limitations should be taken into account.

One of these is the inferences regarding the causal interrelationship of behavioural, normative and control beliefs, intention and behaviours, when only a few studies directly investigated the role of attitudes, subjective norms and perceived behavioural control in mediating the effects of NEs that promote PA. The link of beliefs, intention and behaviour is therefore partially deductive in this review. Another limitation concerns the possibility of not being able to include all the available literature. Only peer-reviewed journal articles were included, which, on one the hand, guarantees a minimum quality standard for the reviewed publications, but, on the other, may have excluded a number of other studies (i.e. grey literature). Finally, due to the large variety of study designs, it was not possible to conduct a proper assessment of quality through a standardized instrument.

\section{Implications for health-promotion interventions}

On consideration of the application of our findings and the proposed theoretical model, a number of recommendations for future PA-promoting interventions are formulated:

o Social campaigns promoting visits to NEs and active living should focus on individual targeted beliefs that sustain people's intention to engage in PA. Health benefits and stress-relieving effects of being in touch with nature, as well as the advantages of using NEs as a strategy to sustain PA for fitness and aesthetic purposes, must be used in messages to the community. Such communication can consist of both public campaigns and individual messages via family doctors. The latter might be particularly relevant in impacting on people's subjective norms.

o Programming of activities that aim to promote social interactions and positive experiences in NEs, such as organizing walking groups or other group activities, may encourage people to visit NEs and engage in PA.

o Information about the health benefits of being in touch with nature, provided by family doctors, as well as school-based 'outdoor education', may 
positively impact on individual subjective norms as well as attitudes towards outdoor recreation via feelings about nature.

o The quality of an NE, especially with respect to safety, aesthetics and accessibility, plays a central role in determining its use for PA purposes. It is therefore of paramount importance to guarantee availability of quality NEs to promote active living through urban/ infrastructural interventions. However, as the presence of infrastructures facilitating PA alone does not automatically mean that people will use NEs, accessibility, good maintenance and information must be involved too.

\section{Recommendation for future research}

The conceptual model explaining motivation for PA in NEs presented here provides us with an alternative way to approach personal (i.e. salient beliefs that have room for improvement in a TPB prediction equation) and environmental factors in which we may intervene. Future studies, especially those using an experimental design, should explore the relationship between availability of NEs within the living environment and PA. It is not clear to what extent and how an individual's feelings about nature can influence the NE-PA relationship and the psychological states associated with experiences in NEs, so researchers should also consider these variables in future studies.

\section{Conclusions}

Natural environments such as green or open spaces, but also attractive views of nature integrated within the urban landscape, are important environmental factors sustaining PA in the population. Individual characteristics and environmental barriers may, however, impact the relationship between availability of NEs and PA behaviours. PA-promoting interventions should aim to guarantee access and good maintenance of NEs. Information and programming of social activities may also encourage more use of NEs. Social campaigns via media and health institutions should advertise how nature can help motivate maintenance of a PA routine, reduce stress, and achieve aesthetic and health goals.

\section{Abbreviations}

ART: Attention-restoration theory; NE: Natural environment; PA: Physical activity; TPB: Theory of planned behaviour; WHO: World Health Organization.

\section{Competing interests}

The authors declare that they have no competing interests.

\section{Authors' contributions}

GC was responsible for the conception of the work, carried out the literature search and integration of the framework, and drafted the manuscript. SC provided substantial contributions to revision of the intellectual content and final development and write up of the manuscript. Both authors approved the final manuscript
Acknowledgments

We acknowledge Professor Camilla Martha Iklebæk for her insight and initial support.

\section{Author details}

${ }^{1}$ Department of Dental Care and Public Health, Hedmark University College, Elverum, Norway. ${ }^{2}$ Department of Sports and Physical Education, Hedmark University College, Elverum, Norway.

Received: 22 April 2014 Accepted: 8 August 2014

Published: 24 August 2014

\section{References}

1. World Health Organization: Global Recommendations on Physical Activity for Health. Geneva: WHO; 2010.

2. Sallis JF, Cervero RB, Ascher W, Henderson KA, Kraft MK, Kerr J: An ecological approach to creating active living communities. Annu Rev Public Health 2006, 27:297-322.

3. Sharpe PA, Granner ML, Hutto B, Ainsworth BE: Association of environmental factors to meeting physical activity recommendations in two South Carolina counties. Am J Health Promot 2004, 18:251-257.

4. Nelson NM, Wright A, Lowry RG, Mutrie N: Where is the theoretical basis for understanding and measuring the environment for physical activity? Environ Health Insights 2008, 2:111-116.

5. Bedimo-Rung AL, Mowen AJ, Cohen DA: The significance of parks to physical activity and public health - A conceptual model. Am J Prev Med 2005, 28:159-168.

6. Barton H: Land use planning and health and well-being. Land Use Policy 2009, 26:S115-S123.

7. Grinde B, Patil GG: Biophilia: Does visual contact with nature impact on health and well-being? Int J Environ Res Public Health 2009, 6:2332-2343.

8. Kaczynski AT, Henderson KA: Environmental correlates of physical activity: A review of evidence about parks and recreation. Leis Sci 2007, 29:315-354.

9. Lee ACK, Maheswaran R: The health benefits of urban green spaces: a review of the evidence. J Public Health 2011, 33:212-222.

10. Bowler DE, Buyung-Ali LM, Knight TM, Pullin AS: A systematic review of evidence for the added benefits to health of exposure to natural environments. BMC Public Health 2010, 10:1471-2458.

11. Thompson Coon J, Boddy K, Stein K, Whear R, Barton J, Depledge MH: Does participating in physical activity in outdoor natural environments have a greater effect on physical and mental wellbeing than physical activity indoors? A systematic review. Environ Sci Technol 2011, 45:1761-1772.

12. Gelter H: Friluftsliv: The Scandinavian philosophy of outdoor life. Can J Environ Educ 2000, 5:77-92.

13. Morris N: Health, well-being and open space. Edinburgh: Edinburgh College of Art and Heriot-Watt University; 2003.

14. Gladwell VF, Brown DK, Wood C, Sandercock GR, Barton JL: The great outdoors: how a green exercise environment can benefit all. Extreme Physiol Med 2013, 2:3.

15. Juster RP, McEwen BS, Lupien SJ: Allostatic load biomarkers of chronic stress and impact on health and cognition. Neurosci Biobehav Rev 2010, 35:2-16.

16. Ulrich RS, Simons RF, Losito BD, Fiorito E, Miles MA, Zelson M: Stress recovery during exposure to natural and urban environments. J Environ Psychol 1991, 11:201-203.

17. Kaplan R: The experience of nature: a psychological perspective. Cambridge: Cambridge University Press; 1989.

18. Gladwell VF, Brown DK, Barton JL, Tarvainen MP, Kuoppa P, Pretty J, Suddaby JM, Sandercock GRH: The effects of views of nature on autonomic control. Eur J Appl Physiol 2012, 112:3379-3386.

19. Ulrich RS: View through a window may influence recovery from surgery. Science 1984, 224:420-421.

20. Raanaas RK, Patil GG, Hartig T: Health benefits of a view of nature through the window: a quasi-experimental study of patients in a residential rehabilitation center. Clin Rehabil 2012, 26:21-32.

21. Akers A, Barton J, Cossey R, Gainsford P, Griffin M, Micklewright D: Visual color perception in green exercise: positive effects on mood and perceived exertion. Environ Sci Technol 2012, 46:8661-8666.

22. Li Q: Effect of forest bathing trips on human immune function. Environ Health Prev Med 2010, 15:9-17. 
23. Fan $Y$, Das KV, Chen Q: Neighborhood green, social support, physical activity, and stress: assessing the cumulative impact. Health Place 2011, 17:1202-1211

24. Sugiyama T, Leslie E, Giles-Corti B, Owen N: Associations of neighbourhood greenness with physical and mental health: do walking, social coherence and local social interaction explain the relationships? J Epidemiol Commun Health 2008, 62(5):e9.

25. Aspinall $P$, Mavros $P$, Coyne $R$, Roe J: The urban brain: analysing outdoor physical activity with mobile EEG. Br J Sports Med 2013, epub March 6.

26. van den Berg AE, Maas J, Verheij RA, Groenewegen PP: Green space as a buffer between stressful life events and health. Soc Sci Med 2010, 70:1203-1210.

27. Thompson CW, Roe J, Aspinall P, Mitchell R, Clow A, Miller D: More green space is linked to less stress in deprived communities: Evidence from salivary cortisol patterns. Landscape Urban Plann 2012, 105:221-229

28. Ajzen I: The theory of planned behavior. Organ Behav Hum Decis Process 1991, 50:179-211.

29. Ajzen I, Brown TC, Carvajal F: Explaining the discrepancy between intentions and actions: The case of hypothetical bias in contingent valuation. Pers Soc Psychol B 2004, 30:1108-1121.

30. Ajzen I: Perceived behavioral control, self-efficacy, locus of control, and the theory of planned behavior. J Appl Soc Psychol 2002, 32:665-683

31. Rhodes RE, Brown SG, Mclntyre CA: Integrating the perceived neighborhood environment and the theory of planned behavior when predicting walking in a Canadian adult sample. Am J Health Promot 2006, 21:110-118.

32. Kouthouris C, Spontis A: Outdoor recreation participation: an application of the theory of planned behavior. Sport J 2005, 8(3).

33. Focht BC: Brief walks in outdoor and laboratory environments: effects on affective responses, enjoyment, and intentions to walk for exercise. Res Q Exerc Sport 2009, 80:611-620.

34. Dasilva SG, Guidetti L, Buzzachera CF, Elsangedy HM, Krinski K, De Campos W, Goss FL, Baldari C: Psychophysiological responses to self-paced treadmill and overground exercise. Med Sci Sports Exerc 2011, 43:1114-1124.

35. Whittemore R, Knafl K: The integrative review: updated methodology. J Adv Nurs 2005, 52:546-553.

36. Moher D, Liberati A, Tetzlaff J, Altman DG, Grp P: Preferred reporting items for systematic reviews and meta-analyses: The PRISMA statement. Int J Surg 2010, 8:336-341.

37. Des Jarlais DC, Feelemyer JP, Modi SN, Abdul-Quader A, Hagan H: High coverage needle/syringe programs for people who inject drugs in low and middle income countries: a systematic review. BMC Public Health 2013, 13:53.

38. Lu M, Moritz S, Lorenzetti D, Sykes L, Straus S, Quan H: A systematic review of interventions to increase breast and cervical cancer screening uptake among Asian women. BMC Public Health 2012, 12:413.

39. Aveyard H: Doing a Literature Review in Health and Social Care: A practical guide. Maidenhead: McGraw-Hill/Open University Press; 2014.

40. Harte $J L$, Eifert $\mathrm{GH}$ : The effects of running, environment, and attentional focus on athletes catecholamine and cortisol-levels and mood. Psychophysiology 1995, 32:49-54.

41. Kerr JH, Fujiyama H, Sugano A, Okamura T, Chang ML, Onouha F: Psychological responses to exercising in laboratory and natural environments. Psychol Sport Exerc 2006, 7:345-359.

42. Hartig T, Mang M, Evans GW: Restorative effects of natural environment experiences. Environ Behav 1991, 23:3-26.

43. Hartig T, Evans GW, Jamner LD, Davis DS, Garling T: Tracking restoration in natural and urban field settings. J Environ Psychol 2003, 23:109-123.

44. Bodin M, Hartig T: Does the outdoor environment matter for psychological restoration gained through running? Psychol Sport Exerc 2003, 4:141-153.

45. Pretty J, Peacock J, Sellens M, Griffin M: The mental and physical health outcomes of green exercise. Int J Environ Health Res 2005, 15:319-337.

46. Pretty J, Peacock J, Hine R, Sellens M, South N, Griffin M: Green exercise in the UK countryside: Effects on health and psychological well-being, and implications for policy and planning. J Environ Plann Manag 2007, 50:211-231

47. Park BJ, Tsunetsugu Y, Kasetani T, Kagawa T, Miyazaki Y: The physiological effects of Shinrin-yoku (taking in the forest atmosphere or forest bathing): evidence from field experiments in 24 forests across Japan. Environ Health Prev Med 2010, 15:18-26.

48. Barton J, Pretty J: What is the best dose of nature and green exercise for improving mental health? A multi-study analysis. Environ Sci Technol 2010, 44:3947-3955

49. Ryan RM, Weinstein N, Bernstein J, Brown KW, Mistretta L, Gagne M: Vitalizing effects of being outdoors and in nature. J Environ Psycho/ 2010 30:159-168.

50. Butryn TM, Furts DM: The effects of park and urban settings on the moods and cognitive strategies of female runners. J Sport Behav 2003, 26:335.

51. Morita E, Fukuda S, Nagano J, Hamajima N, Yamamoto H, Iwai Y, Nakashima T, Ohira H, Shirakawa T: Psychological effects of forest environments on healthy adults: Shinrin-yoku (forest-air bathing, walking) as a possible method of stress reduction. Public Health 2007, 121:54-63.

52. Berman MG, Jonides J, Kaplan S: The cognitive benefits of interacting with nature. Psychol Sci 2008, 19:1207.

53. Mayer FS, Frants CM, Bruehlman-Senecal E, Dolliver K: Why is nature beneficial?: the role of connectedness to nature. Environ Behav 2009, 41:607-643

54. van den Berg AE, Custers MHG: Gardening promotes neuroendocrine and affective restoration from stress. J Health Psychol 2011, 16:3-1053.

55. Mao GX, Lan XG, Cao YB, Chen ZM, He ZH, Lv YD, Wang YZ, Hu XL, Wang GF, Yan J: Effects of short-term forest bathing on human health in a broad-leaved evergreen forest in Zhejiang Province, China. Biomed Environ Sci 2012, 25:317-324.

56. Cerin E, Vandelanotte C, Leslie E, Merom D: Recreational facilities and leisure-time physical activity: An analysis of moderators and self-efficacy as a mediator. Health Psychol 2008, 27(Suppl):S126-S135.

57. Mitchell R: Is physical activity in natural environments better for mental health than physical activity in other environments? Soc Sci Med 2012, $8: 8$

58. Orsega-Smith E, Mowen AJ, Payne LL, Godbey G: The interaction of stress and park use on psycho-physiological health in older adults. J Leis Res 2004, 36:232-256.

59. Hug SM, Hartig T, Hansmann R, Seeland K, Hornung R: Restorative qualities of indoor and outdoor exercise settings as predictors of exercise frequency. Health Place 2009, 15:971-980.

60. Gatersleben B, Andrews M: When walking in nature is not restorative The role of prospect and refuge. Health Place 2013, 20:91.

61. Li Q, Otsuka T, Kobayashi M, Wakayama Y, Inagaki H, Katsumata M, Hirata Y, Li Y, Hirata K, Shimizu T, Suzuki H, Kawada T, Kagawa T: Acute effects of walking in forest environments on cardiovascular and metabolic parameters. Eur J Appl Physiol 2011, 111:2845-2853.

62. Yamaguchi M, Deguchi M, Miyazaki Y: The effects of exercise in forest and urban environments on sympathetic nervous activity of normal young adults. J Int Med Res 2006, 34:152-159.

63. Karusisi N, Bean K, Oppert JM, Pannier B, Chaix B: Multiple dimensions of residential environments, neighborhood experiences, and jogging behavior in the RECORD Study. Prev Med 2012, 55:50-55.

64. Hoehner CM, Brownson RC, Allen D, Gramann J, Behrens TK, Floyd MF, Leahy J, Liddle JB, Smaldone D, Spain DD, Tardona DR, Ruthmann NP, Seiler RL, Yount BW: Parks promoting physical activity: synthesis of findings from interventions in seven national parks. J Phys Act Health 2010, 7(Suppl 1):S67-S81.

65. Bai H, Stanis SAW, Kaczynski AT, Besenyi GM: Perceptions of neighborhood park quality: associations with physical activity and body mass index. Ann Behav Med 2013, 45:S39-S48.

66. Ries AV, Voorhees CC, Roche KM, Gittelsohn J, Yan AF, Astone NM: A quantitative examination of park characteristics related to park use and physical activity among urban youth. J Adolesc Health 2009, 45(3 Suppl):S64-S70.

67. Scott $D$, Jackson EL: Factors that limit and strategies that may encourage people's use of public parks. J Park Recreation Admin 1996, 4:1-17.

68. Mason P, Kearns A, Bond L: Neighbourhood walking and regeneration in deprived communities. Health Place 2011, 17:727-737.

69. Lackey KJ, Kaczynski AT: Correspondence of perceived vs. objective proximity to parks and their relationship to park-based physical activity. Int J Behav Nutr Phy 2009, 6

70. Prince SA, Kristjansson EA, Russell K, Billette JM, Sawada M, Ali A, Tremblay MS, Prud'homme D: A multilevel analysis of neighbourhood built and social 
environments and adult self-reported physical activity and body mass index in Ottawa, Canada. Int J Environ Res Public Health 2011, 8:3953-3978.

71. Prince SA, Kristjansson EA, Russell K, Billette JM, Sawada MC, Ali A, Tremblay MS, Prud'homme D: Relationships between neighborhoods, physical activity, and obesity: a multilevel analysis of a large Canadian city. Obesity 2012, 20:2093-2100

72. Shores KA, West ST, Theriault DS, Davison EA: Extra-individual correlates of physical activity attainment in rural older adults. J Rural Health 2009, 25:211-218

73. Wen M, Kandula NR, Lauderdale DS: Walking for transportation or leisure: what difference does the neighborhood make? J Gen Intern Med 2007, 22:1674-1680.

74. Mowen A, Orsega-Smith E, Payne L, Ainsworth B, Godbey G: The role of park proximity and social support in shaping park visitation, physical activity, and perceived health among older adults. J Phys Act Health 2007, 4:167-179.

75. Cerin E, Lee KY, Barnett A, Sit CH, Cheung MC, Chan WM: Objectivelymeasured neighborhood environments and leisure-time physical activity in Chinese urban elders. Prev Med 2013, 56:86-89.

76. Cohen DA, McKenzie TL, Sehgal A, Williamson S, Golinelli D, Lurie N: Contribution of public parks to physical activity. Am J Public Health 2007, 97:509-514.

77. Foster C, Hillsdon M, Thorogood M: Environmental perceptions and walking in English adults. J Epidemiol Commun Health 2004, 58:924-928.

78. Gomez LF, Parra DC, Buchner D, Brownson RC, Sarmiento OL, Pinzon JD, Ardila M, Moreno J, Serrato M, Lobelo F: Built environment attributes and walking patterns among the elderly population in Bogota. Am J Prev Med 2010, 38:592-599.

79. Kaczynski AT, Potwarka LR, Smale BJA, Havitz ME: Association of parkland proximity with neighborhood and park-based physical activity: variations by gender and age. Leis Sci 2009, 31:174-191.

80. Michael YL, Perdue LA, Orwoll ES, Stefanick ML, Marshall LM: Physical activity resources and changes in walking in a cohort of older men. Am J Public Health 2010, 100:654-660.

81. Nelson NM, Woods CB: Neighborhood perceptions and active commuting to school among adolescent boys and girls. J Phys Act Health 2010, 7:257-266.

82. Pate RR, Colabianchi N, Porter D, Almeida MJ, Lobelo F, Dowda M: Physical activity and neighborhood resources in high school girls. Am J Prev Med 2008, 34:413-419.

83. Boone-Heinonen J, Casanova K, Richardson AS, Gordon-Larsen P: Where can they play? Outdoor spaces and physical activity among adolescents in U.S. urbanized areas. Prev Med 2010, 51:295-298.

84. Gomez LF, Sarmiento OL, Parra DC, Schmid TL, Pratt M, Jacoby E, Neiman A, Cervero R, Mosquera J, Rutt C, Ardila M, Pinzon JD: Characteristics of the built environment associated with leisure-time physical activity among adults in Bogota, Colombia: a multilevel study. J Phys Act Health 2010, 7(Suppl 2):S196-S203.

85. Kaczynski AT, Potwarka LR, Saelens BE: Association of park size, distance, and features with physical activity in neighborhood parks. Am J Public Health 2008, 98:1451-1456.

86. Wilson LA, Giles-Corti B, Burton NW, Giskes K, Haynes M, Turrell G: The association between objectively measured neighborhood features and walking in middle-aged adults. Am J Health Promot 2011, 25:e12-e21.

87. Stigsdotter UK, Ekholm O, Schipperijn J, Toftager M, Kamper-Jorgensen F Randrup TB: Health promoting outdoor environments - Associations between green space, and health, health-related quality of life and stress based on a Danish national representative survey. Scand $J$ Public Health 2010, 38:411-417.

88. Shores KA, West ST: Pursuing leisure during leisure-time physical activity. J Phys Act Health 2010, 7:685-694.

89. Duvall J, De Young R: Some strategies for sustaining a walking routine: insights from experienced walkers. J Phys Act Health 2013, 10:10-18.

90. Day R: Local environments and older people's health: dimensions from a comparative qualitative study in Scotland. Health Place 2008, 14:299-312

91. Anderson DH, Wilhelm Stanis SA, Schneider IE, Leahy JE: Proximate and distant visitors: Difference in importance ratings of beneficial experiences. J Park Recreation Admin 2008, 26:18.
92. Bjork J, Albin M, Grahn P, Jacobsson H, Ardo J, Wadbro J, Ostergren PO: Recreational values of the natural environment in relation to neighbourhood satisfaction, physical activity, obesity and wellbeing. J Epidemiol Commun Health 2008, 62(4):e2.

93. Coogan PF, White LF, Adler TJ, Hathaway KM, Palmer JR, Rosenberg L: Prospective study of urban form and physical activity in the Black Women's Health Study. Am J Epidemiol 2009, 170:1105-1117.

94. Coombes $\mathrm{E}$, Jones AP, Hillsdon M: The relationship of physical activity and overweight to objectively measured green space accessibility and use. Soc Sci Med 2010, 70:816-822.

95. Coutts C, Chapin T, Horner M, Taylor C: County-level effects of green space access on physical activity. J Phys Act Health 2013, 10:232-240.

96. Cummins S, Fagg J: Does greener mean thinner? Associations between neighbourhood greenspace and weight status among adults in England. Int J Obes 2012, 36:1108-1113.

97. Foster C, Hillsdon M, Jones A, Grundy C, Wilkinson P, White M, Sheehan B, Wareham N, Thorogood M: Objective measures of the environment and physical activity - results of the environment and physical activity study in English adults. J Phys Act Health 2009, 6:S70-\$80.

98. Hillsdon M, Panter J, Foster C, Jones A: The relationship between access and quality of urban green space with population physical activity. Public Health 2006, 120:1127-1132.

99. Kaczynski AT, Mowen AJ: Does self-selection influence the relationship between park availability and physical activity? Prev Med 2011, 52:23-25.

100. King TL, Thornton LE, Bentley RJ, Kavanagh AM: Does parkland influence walking? The relationship between area of parkland and walking trips in Melbourne, Australia. Int J Behav Nutr Phys Act 2012, 9:115.

101. Lee C, Moudon AV: Neighbourhood design and physical activity. Build Res Inf 2008, 36:395-411.

102. Librett JJ, Yore MM, Schmid TL: Characteristics of physical activity levels among trail users in a US national sample. Am J Prev Med 2006, 31:399-405

103. Maas J, Verheij RA, Spreeuwenberg P, Groenewegen PP: Physical activity as a possible mechanism behind the relationship between green space and health: A multilevel analysis. BMC Public Health 2008, 8:206-218.

104. McGinn AP, Evenson KR, Herring AH, Huston SL: The relationship between leisure, walking, and transportation activity with the natural environment. Health Place 2007, 13:588-602.

105. Michimi A, Wimberly MC: Natural environments, obesity, and physical activity in nonmetropolitan areas of the United States. J Rural Health 2012, 28:398-407.

106. Mytton OT, Townsend N, Rutter H, Foster C: Green space and physical activity: an observational study using Health Survey for England data. Health Place 2012, 18:1034-1041.

107. Richardson EA, Pearce J, Mitchell R, Kingham S: Role of physical activity in the relationship between urban green space and health. Public Health 2013, 127:318-324.

108. Rodriguez DA, Cho GH, Evenson KR, Conway TL, Cohen D, Ghosh-Dastidar B, Pickrel JL, Veblen-Mortenson S, Lytle LA: Out and about: association of the built environment with physical activity behaviors of adolescent females. Health Place 2012, 18:55-62.

109. Toftager M, Ekholm O, Schipperijn J, Stigsdotter U, Bentsen P, Gronbaek M, Randrup TB, Kamper-Jorgensen F: Distance to green space and physical activity: a Danish national representative survey. J Phys Act Health 2011, 8:741-749.

110. Ward Thompson C, Curl A, Aspinall P, Alves S, Zuin A: Do changes to the local street environment alter behaviour and quality of life of older adults? The 'DIY Streets' intervention. Br J Sports Med 2012, 14:14.

111. Wen M, Zhang X: Contextual effects of built and social environments of urban neighborhoods on exercise: a multilevel study in Chicago. Am J Health Promot 2009, 23:247-254.

112. West ST, Shores KA, Mudd LM: Association of available parkland, physical activity, and overweight in America's largest cities. J Public Health Manag Pract 2012, 18:423-430.

113. Witten K, Hiscock R, Pearce J, Blakely T: Neighbourhood access to open spaces and the physical activity of residents: A national study. Prev Med 2008, 47:299-303.

114. Pereira G, Foster S, Martin K, Christian H, Boruff BJ, Knuiman M, Giles-Corti B: The association between neighborhood greenness and cardiovascular disease: an observational study. BMC Public Health 2012, 12:466. 
115. Levine JA: Nonexercise activity thermogenesis (NEAT): environment and biology. Am J Physiol Endocrinol Metab 2004, 286:E675-E685.

116. Matthews CE, George SM, Moore SC, Bowles HR, Blair A, Park Y, Troiano RP Hollenbeck A, Schatzkin A: Amount of time spent in sedentary behaviors and cause-specific mortality in US adults. Am J Clin Nutr 2012, 95:437-445.

doi:10.1186/1471-2458-14-873

Cite this article as: Calogiuri and Chroni: The impact of the natural environment on the promotion of active living: An integrative systematic review. BMC Public Health 2014 14:873.

\section{Submit your next manuscript to BioMed Central} and take full advantage of:

- Convenient online submission

- Thorough peer review

- No space constraints or color figure charges

- Immediate publication on acceptance

- Inclusion in PubMed, CAS, Scopus and Google Scholar

- Research which is freely available for redistribution 